\title{
Acid-Base Equilibria in Nonpolar Media. 4. Extension of Basicity Scale in THF Medium. Gas-phase basicities of phosphazenes
}

Ivari Kaljurand, ${ }^{\dagger}$ Toomas Rodima, ${ }^{\dagger}$ Aino Pihl, ${ }^{\dagger}$ Vahur Mäemets, ${ }^{\dagger}$ Ivo Leito, ${ }^{* \dagger}$ Ilmar A. Koppel ${ }^{\dagger}$ and Masaaki Mishima

Department of Chemistry, University of Tartu, Jakobi 2, 51014 Tartu, Estonia

Institute for Materials Chemistry and Engineering, Kyushu University, 6-10-1 Hakozaki, Higashi-ku, Fukuoka 812-8581 Japan

\section{Supporting Information}

Table of Contents

Chemicals, Synthesis, Purification and Characterization of Compounds

........ Page S2

References Page S11

Table S1. Experimental results for UV-vis spectrophotometric measurements in THF _.. Page S13

Figures S2. ${ }^{13} \mathrm{C}-\mathrm{NMR}$ spectra of selected compounds Page S16

\footnotetext{
* E-mail: leito@ut.ee; Phone: +372 7375 259; FAX: +372 7375264.

University of Tartu

${ }^{*}$ Kyushu University
} 


\section{Chemicals, Synthesis, Purification and Characterization of Compounds}

Chemicals. p-Anisidine was purified by recrystallization from ethanol-water mixture. All other anilines used for synthesis as well as 1,3,4,6,7,8-hexahydro-1-methyl-2H-pyrimido[1,2-a]pyrimidine (MTBD, 22), $\mathrm{Me}_{3} \mathrm{SiCCl}_{3}$, $\left(\mathrm{Me}_{2} \mathrm{~N}\right)_{3} \mathrm{P}$, potassium methylate (30\% solution in methanol) and pyrrolidine were of commercial origin. Compounds 2, 8, 9 (TBD - 1,3,4,6,7,8-hexahydro-2H-pyrimido[1,2-a]pyrimidine), 12, 16, 17, 19, 21, 23-28, 3034 (see Table 2 and 3 in the main text) were the same as used earlier. ${ }^{1} \mathrm{MeP}_{1}(\mathrm{dma})(\mathbf{1 4})$ was synthesized as described in ref $2 . \mathrm{HP}_{1}(\mathrm{dma})(\mathbf{1 8})$ was synthesized according to procedure described in refs 3 and 4 , and $\mathrm{HP}_{1}$ (pyrr) (13) as described in ref 5. 1,3,4,6,7,8-hexahydro-1-isopropyl-2H-pyrimido[1,2-a]pyrimidine (ITBD, 35) was a kind donation from Prof. Reinhard Schwesinger (University of Freiburg). Solution of methanesulfonic acid $\left(\mathrm{MeSO}_{3} \mathrm{H}\right)(>99 \%)$ was used as acidic titrant. Phosphazene bases $\mathrm{EtP}_{2}(\mathrm{dma})(\mathbf{2})(>98 \%)$ or synthesized $t$ $\mathrm{BuP}_{4}(\mathrm{dma})^{8}$ were used as basic titrants. THF was used as purchased $(99.9 \%$, Super Purity Solvent, water content stated by producer $<0.005 \%)$.

Synthesis of $\mathbf{P h P}_{\mathbf{1}}(\mathbf{d m a})_{2} \mathbf{M e}(\mathbf{2 9})$. To a solution of $15 \mathrm{mmol}(2.0 \mathrm{~g})$ methyl-bis(dimethylamino)phosphine synthesized from $\left(\mathrm{Me}_{2} \mathrm{~N}\right)_{2} \mathrm{PCl}$ and $\mathrm{MeLi}$ as described by Nöth and Vetter ${ }^{6}$, in $10 \mathrm{~mL}$ of dry benzene at $25-50^{\circ} \mathrm{C}$ was added drop wise a solution of $15 \mathrm{mmol}(1.78 \mathrm{~g})$ of phenyl azide ${ }^{7}$ in $10 \mathrm{~mL}$ of benzene. The mixture was refluxed for $2 \mathrm{hr}$. Benzene was removed in vacuo and the residue was distilled. A fraction boiling at $121-122^{\circ} \mathrm{C} /$ $0.49 \mathrm{mmHg}$ was collected to give a colorless liquid which in receiver solidified (mp 62.0 $-64.5^{\circ} \mathrm{C}$, yield $3.3 \mathrm{~g}$, $73 \%$ ). Anal. Calcd. for $\mathrm{C}_{11} \mathrm{H}_{20} \mathrm{~N}_{3} \mathrm{P}: \mathrm{C}, 58.65 \% ; \mathrm{H}, 8.95 \%, \mathrm{~N}, 18.65 \%$. Found: C, 58.52\%; H, 9.00\%; N, $18.44 .{ }^{1} \mathrm{H}$ $\operatorname{NMR}(200 \mathrm{MHz}, \mathrm{MeCN}) \delta 1.47\left(\mathrm{~d}, 3 \mathrm{H}, J_{P-H}=14.0\right), 2.60\left(\mathrm{~d}, 12 \mathrm{H}, J_{P-H}=10.0\right), 6.55\left(\mathrm{~m}, 1 \mathrm{H}, J_{H-H}=7.2\right), 6.62(\mathrm{~m}$, $\left.2 \mathrm{H}, J_{H-H}=8.2\right), 7.00\left(\mathrm{~m}, 2 \mathrm{H}, J_{H-H a v}=7.5\right) .{ }^{13} \mathrm{C} \mathrm{NMR}(50 \mathrm{MHz}, \mathrm{MeCN}) \delta 9.5\left(\mathrm{~d}, J_{C-P}=112.5\right), 36.9\left(\mathrm{~d}, J_{C-P}=2.7\right)$, $117.2,123.7\left(\mathrm{~d}, J_{C-P}=17.4\right), 129.6,153.1$. 
Synthesis of $\mathbf{P}_{3}$-phosphazenes. The new phenylsubstituted $\mathrm{P}_{3}$-phosphazenes were synthesized by the Kirsanov reaction (Scheme 1) or by the Staudinger reaction (Scheme 2). Caution! Azides (Staudinger reaction) are hazardous (explosive) compounds! Care must be exercised, large amounts must not be used. Their $\mathrm{HBF}_{4}$ or $\mathrm{HBPh}_{4}$ salts were prepared and purified by recrystallisation. Free bases were liberated from their salts by means of MeOK as described earlier. ${ }^{1,8}$ The reaction conditions (and therefore the isolated yields) for all synthesized phosphazene compounds were not optimized.

\section{Scheme 1}

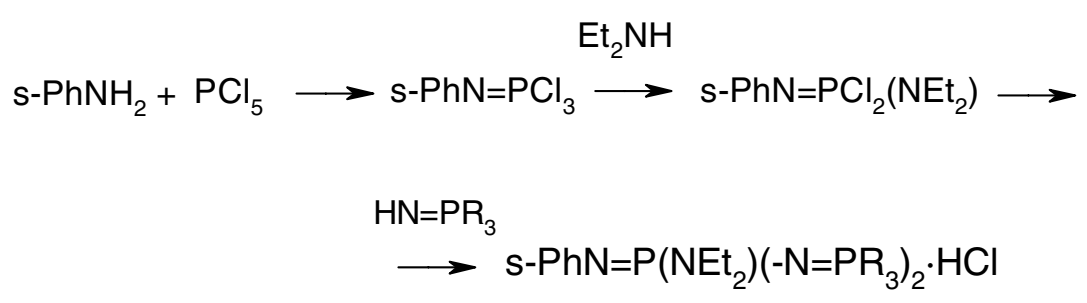

where $\mathrm{R}=-\mathrm{NMe}_{2}$ or 1-pyrrolidinyl radical

\section{Scheme 2}

$$
\mathrm{s}-\mathrm{PhN}_{3}+\mathrm{RPCl}_{2} \longrightarrow \mathrm{s}-\mathrm{PhN}=\mathrm{PCl}_{2} \mathrm{R} \longrightarrow \mathrm{HN}=\mathrm{PR}_{3}
$$

where $\mathrm{R}=-\mathrm{NMe}_{2}$ or 1-pyrrolidinyl radical.

\section{2,5- $\left.\mathbf{C l}_{2}-\mathbf{C}_{6} \mathbf{H}_{3} \mathbf{P}_{\mathbf{3}}(\mathbf{p y r r})_{\mathbf{6}} \mathbf{N E t}_{2} \cdot \mathbf{H B F}_{\mathbf{4}}, \mathbf{( 2 0} \cdot \mathbf{H B F}_{\mathbf{4}}\right)$ (Scheme 1). Five mmol (1.48 g) 2,5- $\mathrm{Cl}_{2} \mathrm{C}_{6} \mathrm{H}_{3} \mathrm{~N}=\mathrm{PCl}_{3}{ }^{9}$ was}

dissolved in $25 \mathrm{~mL}$ dry boiling benzene. At room temperature a solution of $5 \mathrm{mmol}(0.36 \mathrm{~g})$ of $\mathrm{Et}_{2} \mathrm{NH}_{\text {in }} 1 \mathrm{~mL}$ benzene was dropped into the solution following the solution of $5 \mathrm{mmol}(0.51 \mathrm{~g})$ of $\mathrm{Et}_{3} \mathrm{~N}$ in $2 \mathrm{~mL}$ of benzene. The mixture was stirred and slowly heated to $65^{\circ} \mathrm{C}$ for $1 \mathrm{hr}$ and left then for overnight. Precipitated $\mathrm{Et}{ }_{3} \mathrm{~N} \cdot \mathrm{HCl}$ was filtered off and to the benzene solution $20 \mathrm{mmol}(5.12 \mathrm{~g})$ of $\mathrm{HP}_{1}$ (pyrr) was added by means of dropping funnel. The mixture was refluxed for $2 \mathrm{hr}$, benzene distilled off (finally at reduced pressure) and residue was heated at $130{ }^{\circ} \mathrm{C}$ for $6 \mathrm{hr}$. After that some benzene or toluene was added and solution was left for overnight at 5 ${ }^{\circ} \mathrm{C}$ to precipitate of $\mathrm{HP}_{1}(\mathrm{pyrr}) \cdot \mathrm{HCl}$. The mixture was filtered, solvent and excess of $\mathrm{HP}_{1}(\mathrm{pyrr})$ removed under 
reduced pressure. The residue was dissolved in $40 \mathrm{ml} 70 \% \mathrm{EtNH}_{2}$ aq soln and once more filtered. To the filtrate a solution of $5 \mathrm{mmol}(0.55 \mathrm{~g})$ of $\mathrm{NaBF}_{4}$ in minimum amount of water was added, and then water up to turbidity. A day later crystals of product were filtered off and recrystallized from ethyl acetate to give $1.2 \mathrm{~g}$ of colorless needles (mp 156.8-157.7 ${ }^{\circ} \mathrm{C}$, yield 28\%). Anal. Calcd. for $\mathrm{C}_{34} \mathrm{H}_{62} \mathrm{BF}_{4} \mathrm{Cl}_{2} \mathrm{~N}_{10} \mathrm{P}_{3}: \mathrm{C}, 47.40 \% ; \mathrm{H}, 7.25 \% ; \mathrm{N}, 16.26 \%$. Found: C, 47.60\%; H, 7.13\%; N, 16.04\%. ${ }^{1} \mathrm{H}$ NMR (200 MHz, $\left.\mathrm{CDCl}_{3}\right) \delta 1.05\left(\mathrm{t}, 6 \mathrm{H}, J_{H-H}=7.1\right), 1.85(\mathrm{~m}, 24 \mathrm{H})$, $3.13\left(\mathrm{dt}, 24 \mathrm{H}, J_{P-H}=3.6, J_{H-H}=6.5\right), 3.19\left(\mathrm{dq}, 4 \mathrm{H}, J_{P-H}=12.6, J_{H-H}=7.1\right), 5.56\left(\mathrm{~d}, 1 \mathrm{H}, J_{P-H}=9.2\right), 6.81\left(\mathrm{dd}, 1 \mathrm{H}, J_{H-}\right.$ $\left.{ }_{H}=8.5, J_{H-H}=2.4\right), 7.24\left(\mathrm{dd}, 1 \mathrm{H}, J_{H-H}=8.5, J_{P-H}=1.3\right), 7.33\left(\mathrm{~d}, 1 \mathrm{H}, J_{H-H}=2.4\right) .{ }^{13} \mathrm{C} \mathrm{NMR}\left(50 \mathrm{MHz}, \mathrm{CDCl}_{3}\right) \delta 14.0$ $\left(\mathrm{d}, J_{C-P}=3.2\right), 26.4\left(\mathrm{~d}, J_{C-P}=8.8\right), 40.0\left(\mathrm{~d}, J_{C-P}=6.1\right), 46.9\left(\mathrm{~d}, J_{C-P}=5.0\right), 117.7\left(\mathrm{~d}, J_{C-P}=2.7\right), 119.1\left(\mathrm{~d}, J_{C-P}=\right.$ $10.8), 120.7,129.9,133.0,139.3\left(\mathrm{~d}, J_{C-P}=2.3\right)$.

2-Cl- $\mathbf{C}_{6} \mathbf{H}_{4} \mathbf{P}_{3}(\mathbf{d m a})_{6} \mathbf{N E t}_{2} \cdot \mathbf{H B F}_{4},\left(\mathbf{1 5} \cdot \mathbf{H B F}_{4}\right)$ (Scheme 1). The same procedure was used as for the synthesis of $\mathbf{2 0} \cdot \mathrm{HBF}_{4}$. From $7 \mathrm{mmol}$ of $2-\mathrm{Cl}-\mathrm{C}_{6} \mathrm{H}_{4} \mathrm{~N}=\mathrm{PCl}_{3}{ }^{10}$ in $35 \mathrm{ml}$ of benzene, $7 \mathrm{mmol}$ of $\mathrm{Et}_{2} \mathrm{NH}, 7 \mathrm{mmol}$ of $\mathrm{Et}_{3} \mathrm{~N}$ and 28 mmol of $\mathrm{HP}_{1}(\mathrm{dma})$ as starting materials $\mathbf{1 5} \cdot \mathbf{H C l}$ salt was obtained as brown oil. This was dissolved in $25 \mathrm{~mL}$ $70 \% \mathrm{EtNH}_{2}$ aq soln, calculated amount of $\mathrm{NaBF}_{4}$ was added and $\mathbf{1 5} \cdot \mathbf{H B F} \mathbf{4}$ was extracted with methylene chloride. Solvent was removed (finally at $130{ }^{\circ} \mathrm{C} / 0.2 \mathrm{mmHg}$ ). The residue $(3.6 \mathrm{~g}$ ) was treated with $3 \mathrm{~mL}$ of $70 \%$ EtNH ${ }_{2}$ aq soln, stirred with glass stick and $\mathbf{1 5} \cdot \mathbf{H B F}_{\mathbf{4}}$ raw crystals were collected. Recrystallization was made from ethyl acetate to give $1.7 \mathrm{~g}$ of colorless crystals (mp 144.3-145.0 ${ }^{\circ} \mathrm{C}$, yield $36 \%$ ). Anal. Calcd. for $\mathrm{C}_{22} \mathrm{H}_{51} \mathrm{BF}_{4} \mathrm{ClN}_{10} \mathrm{P}_{3}: \mathrm{C}, 39.39 \% ; \mathrm{H}, 7.66 \% ; \mathrm{N}, 20.88 \%$. Found: C, 39.57\%; H, 7,59\%, N, 20.72\%. ${ }^{1} \mathrm{H}$ NMR (200 $\left.\mathrm{MHz}, \mathrm{CDCl}_{3}\right) \delta 1.05\left(\mathrm{t}, 6 \mathrm{H}, J_{H-H}=7.1\right), 2.66\left(\mathrm{~d}, 36 \mathrm{H}, J_{P-H}=10.3\right), 3.19\left(\mathrm{dq}, 4 \mathrm{H}, J_{P-H}=12.6, J_{H-H}=7.1\right), 5.47(\mathrm{~d}$, $\left.1 \mathrm{H}, J_{P-H}=9.2\right), 6.85\left(\mathrm{ddd}, 1 \mathrm{H}, J_{H-H}=2.1, J_{H-H}=6.9, J_{H-H}=8.0\right), 7.1-7.3(\mathrm{~m}, 3 \mathrm{H}) .{ }^{13} \mathrm{C} \mathrm{NMR}\left(50 \mathrm{MHz}, \mathrm{CDCl}_{3}\right)$ $\delta 13.9\left(\mathrm{~d}, J_{C-P}=3.2\right), 37.1\left(\mathrm{~d}, J_{C-P}=4.6\right), 29.8\left(\mathrm{~d}, J_{C-P}=6.1\right), 117.7\left(\mathrm{~d}, J_{C-P}=2.9\right), 121.1\left(\mathrm{~d}, J_{C-P}=11.2\right), 121.4$, $127.5,129.3138 .0\left(\mathrm{~d}, J_{C-P}=2.6\right)$.

2-Cl- $\mathbf{C}_{6} \mathbf{H}_{4} \mathbf{P}_{3}(\text { pyrr })_{6} \mathbf{N E t}_{2} \cdot \mathbf{H B P h}_{4},\left(\mathbf{1 1} \cdot \mathbf{H B P h}_{4}\right)($ Scheme 1$)$. The same procedure was used as for synthesis of 15. $\mathrm{HBF}_{4}$. From $4.8 \mathrm{mmol}$ of $2-\mathrm{Cl}-\mathrm{C}_{6} \mathrm{H}_{4} \mathrm{~N}=\mathrm{PCl}_{3}, 4.8 \mathrm{mmol}$ of $\mathrm{Et}_{2} \mathrm{NH}, 4.8 \mathrm{mmol}$ of $\mathrm{Et}_{3} \mathrm{~N}$ and $15.4 \mathrm{mmol}$ of $\mathrm{HP}_{1}$ (pyrr) as starting compounds $4.2 \mathrm{~g}$ of raw $\mathbf{1 1} \cdot \mathbf{H B F} \mathbf{F}_{\mathbf{4}}$ was obtained as a brown oil. This was dissolved in 15 $\mathrm{mL}$ of $\mathrm{MeOH}$ and $5 \mathrm{mmol}$ of $\mathrm{NaBPh}_{4}$ in $10 \mathrm{~mL}$ of $\mathrm{MeOH}$ was added. Light brown oil was settled out, which 
soon solidified for beige crystalline mass. Recrystallization was made from 1:3 mixture of $\mathrm{MeCN} / \mathrm{MeOH}$ to give $2.4 \mathrm{~g}$ of $\mathbf{1 1} \cdot \mathbf{H B P h}_{4}\left(\mathrm{mp} 185.8-186.9^{\circ} \mathrm{C}\right.$, yield $\left.47 \%\right)$. Anal. Calcd. for $\mathrm{C}_{58} \mathrm{H}_{83} \mathrm{BClN}_{10} \mathrm{P}_{3}: \mathrm{C}, 65.75 \% ; \mathrm{H}$, 7.90\%; N,13.22\%. Found: C,66.12\%; H, 7.72\%; N, 13.12\%. ${ }^{1} \mathrm{H}$ NMR $\left(200 \mathrm{MHz}, \mathrm{CDCl}_{3}\right) \delta 1.01\left(\mathrm{t}, 6 \mathrm{H}, J_{H-H}=\right.$ $7.1), 1.76(\mathrm{~m}, 24 \mathrm{H}), 3.05\left(\mathrm{dt}, 24 \mathrm{H}, J_{H-H}=6.6, J_{P-H}=3.6\right), 3.15\left(\mathrm{dq}, 4 \mathrm{H}, J_{P-H}=12.6, J_{H-H}=7.1\right), 5.52\left(\mathrm{~d}, 1 \mathrm{H}, J_{H-H}=\right.$ 9.1), $6.80\left(\mathrm{ddd}, 1 \mathrm{H}, J_{H-H}=2.1, J_{H-H}=6.9, J_{H-H}=8.0\right), 6.88\left(\mathrm{t}, 4 \mathrm{H}, J_{H-H}=7.5\right), 7.04\left(\mathrm{t}, 8 \mathrm{H}, J_{H-H(a v)}=7.5\right), 7.1-7.2(\mathrm{~m}$, 2H). $7.29\left(\mathrm{dt}, 1 \mathrm{H}, J_{H-H}=8.1, J_{H-H}=1.4, J_{P-H}=1.4\right), 7.42(\mathrm{~m}, 8 \mathrm{H}) .{ }^{13} \mathrm{C} \mathrm{NMR}\left(50 \mathrm{MHz}, \mathrm{CDCl}_{3}\right) \delta 13.9\left(\mathrm{~d}, J_{C-P}=\right.$ 3.2), $26.3\left(\mathrm{~d}, J_{C-P}=8.7\right), 39.9\left(\mathrm{~d}, J_{C-P}=6.0\right), 46.8\left(\mathrm{~d}, J_{C-P}=4.9\right), 117.5\left(\mathrm{~d}, J_{C-P}=2.8\right), 120.8\left(\mathrm{~d}, J_{C-P}=11.2\right), 121.2$, $121.4,125.3\left(\mathrm{~J}_{B-C}=2.7\right), 127.3,129.2,136.4,138.1\left(\mathrm{~d}, J_{C-P}=2.6\right), 164.5\left(\mathrm{~J}_{B-C}=49.4\right)$.

4- $\mathrm{CF}_{3}-\mathbf{C}_{6} \mathbf{H}_{4} \mathbf{P}_{3}(\mathbf{d m a}) \cdot \mathbf{H B P h}_{4},(\mathbf{1 0} \cdot \mathbf{H B P h})\left(\right.$ Scheme 2). Five point one mmol (0.95 g) of 4-CF F $_{3}$-phenyl azide synthesized according to general description of ref 11 (bp $30.0-30.5^{\circ} \mathrm{C} / 0.72-0.75 \mathrm{mmHg}, \mathrm{n}^{22}{ }_{\mathrm{D}} 1.4888$, yield $57 \%)$ and dissolved in $3 \mathrm{~mL}$ of dry benzene was slowly added to a solution of $5.1 \mathrm{mmol}(0.74 \mathrm{~g})$ of $\mathrm{Me}_{2} \mathrm{NPCl}_{2}{ }^{6}$ in $20 \mathrm{~mL}$ of benzene. The mixture was refluxed for $2 \mathrm{hr}$, benzene was distilled off and residue was heated for 1 $\mathrm{hr}$ at $120{ }^{\circ} \mathrm{C}$. Then the mixture was left to cool to $80{ }^{\circ} \mathrm{C}, 5 \mathrm{~mL}$ of benzene was added and $18.5 \mathrm{mmol}(3.3 \mathrm{~g})$ of $\mathrm{HP}_{1}(\mathrm{dma})$ in $2 \mathrm{~mL}$ of benzene was dropped into the hot solution. The benzene was again distilled off, residue heated at $120-130{ }^{\circ} \mathrm{C}$ for $40 \mathrm{~min}$ and left then for two days. To the solid mixture $5 \mathrm{~mL}$ of benzene was added, precipitated $\mathrm{HP}_{1}(\mathrm{dma}) \cdot \mathrm{HCl}$ was filtered off and benzene was removed under reduced pressure. Residue, about $3.5 \mathrm{~g}$, was dissolved in $10 \mathrm{~mL}$ of $70 \% \mathrm{EtNH}_{2}$ aq soln $0.6 \mathrm{~g}$ of $\mathrm{NaBF}_{4}$ in small quantity of water was added, and mixture was extracted with methylene chloride. The extract was washed once with water, methylene chloride was removed. Residue was dissolved in some $\mathrm{MeOH}$ and product was precipitated as $\mathrm{HBPh}_{4} \mathrm{salt}_{\text {. }}$

Recrystallization of $2.5 \mathrm{~g}$ raw salt from $65 \mathrm{ml}$ of 1:3 mixture of $\mathrm{CHCl}_{3} / \mathrm{MeOH}$ gave light yellowish needles (mp 170.4-171.2 ${ }^{\circ} \mathrm{C}$, yield 42\%). Anal. Calcd. for $\mathrm{C}_{45} \mathrm{H}_{67} \mathrm{BF}_{3} \mathrm{~N}_{10} \mathrm{P}_{3}: \mathrm{C}, 59.77 \% ; \mathrm{H}, 7.43 \% ; \mathrm{N}, 15.41 \%$. Found: $\mathrm{C}$, $59.51 \% ; \mathrm{H}, 7.35 \% ; \mathrm{N}, 15.36 \% .{ }^{1} \mathrm{H}$ NMR $\left(200 \mathrm{MHz}, \mathrm{CDCl}_{3}\right) \delta 2.48\left(\mathrm{~d}, 36 \mathrm{H}, J_{P-H}=10.2\right), 2.64\left(\mathrm{~d}, 6 \mathrm{H}, J_{P-H}=\right.$ 11.0), $4.85\left(\mathrm{~d}, 1 \mathrm{H}, J_{P-H}=8.5\right), 6.67\left(\mathrm{~d}, 2 \mathrm{H}, J_{H-H}=8.6\right), 6.88\left(\mathrm{t}, 4 \mathrm{H}, J_{H-H}=7.1\right), 7.03\left(\mathrm{t}, 8 \mathrm{H}, J_{H-H(a v)}=7.5\right), 7.4(\mathrm{~m}$, 10H). ${ }^{13} \mathrm{C}$ NMR $\left(50 \mathrm{MHz}, \mathrm{CDCl}_{3}\right) \delta 36.8\left(\mathrm{~d}, J_{C-P}=5.9\right), 36.9\left(\mathrm{~d}, J_{C-P}=4.7\right), 116.6\left(\mathrm{~d}, J_{C-P}=7.2\right), 121.5,122.9(\mathrm{q}$, $\left.J_{C-F}=32.8\right), 124.5\left(\mathrm{q}, J_{C-F}=271.8\right), 125.4\left(J_{C-B}=2.8\right), 126.5\left(\mathrm{q}, J_{C-F}=3.7\right), 136.4,144.1,164.5\left(\mathrm{~J}_{B-C}=49.4\right)$. 
4-CF $\mathbf{C F}_{\mathbf{3}}-\mathbf{C}_{6} \mathbf{H}_{\mathbf{4}} \mathbf{P}_{\mathbf{3}}$ (pyrr) $\mathbf{H B F}_{\mathbf{4}},\left(\mathbf{7} \cdot \mathbf{H B F}_{\mathbf{4}}\right)($ Scheme 2$)$. The same procedure was used as described for $\mathbf{1 0} \cdot \mathbf{H B P h}$. pyrrPCl$_{2}$ (bp $67.0-68.5^{\circ} \mathrm{C} / 2-3 \mathrm{mmHg}$ ) was synthesized following the route described by Burg and Slota ${ }^{12}$ for $\mathrm{Me}_{2} \mathrm{NPCl}_{2}$. To a solution of $5 \mathrm{mmol}(0.86 \mathrm{~g})$ of this dichlorophosphine in $2 \mathrm{~mL}$ of dry benzene at room temperature a solution of $5 \mathrm{mmol}(0.94 \mathrm{~g})$ of $4-\mathrm{CF}_{3}$-phenyl azide in $3 \mathrm{~mL}$ of benzene was added by means of syringe. The solution was heated and benzene distilled off (finally at reduced pressure). The mixture was heated at $120-130{ }^{\circ} \mathrm{C}$ for $1 \mathrm{hr}$. Then at $80{ }^{\circ} \mathrm{C} 5 \mathrm{~mL}$ of benzene was added, following a solution of $15.2 \mathrm{mmol}(3.8 \mathrm{~g})$ of $\mathrm{HP}_{1}$ (pyrr) in $3 \mathrm{~mL}$ benzene. Benzene was distilled off again and residue heated at $120{ }^{\circ} \mathrm{C}$ for $1 \mathrm{hr}$. The solvent was removed in vacuo to give at room temperature a brown glassy solid. This was dissolved in $10 \mathrm{~mL}$ of $70 \%$ $\mathrm{EtNH}_{2}$ aq soln, $0.59 \mathrm{~g}$ of $\mathrm{NaBF}_{4}$ aq soln was added and then some water up to turbidity. A soft crystal mass was precipitated. Recrystallization from ethyl acetate gave 1.8 g 7·HBF 4 (mp 193-195 ${ }^{\circ} \mathrm{C}$, yield $\left.42 \%\right)$. Anal. Calcd. for $\mathrm{C}_{35} \mathrm{H}_{61} \mathrm{BF}_{7} \mathrm{~N}_{10} \mathrm{P}_{3}: \mathrm{C}, 48.96 \% ; \mathrm{H}, 7.16 \% ; \mathrm{N}, 16.31 \%$. Found: $\mathrm{C}, 49.20 \% ; \mathrm{H}, 7.14 \% ; \mathrm{N}, 16.16 \% .{ }^{1} \mathrm{H}$ NMR $(200$ $\left.\mathrm{MHz}, \mathrm{CDCl}_{3}\right) \delta 1.82(\mathrm{~m}, 28 \mathrm{H}), 3.12(\mathrm{~m}, 28 \mathrm{H}), 6.01\left(\mathrm{~d}, 1 \mathrm{H}, J_{P-H}=9.5\right), 7.07\left(\mathrm{~d}, 2 \mathrm{H}, J_{H-H}=8.5\right), 7.42(\mathrm{~m}, 2 \mathrm{H}) .{ }^{13} \mathrm{C}$ $\operatorname{NMR}\left(50 \mathrm{MHz}, \mathrm{CDCl}_{3}\right) \delta 26.5\left(\mathrm{~d}, J_{C-P}=8.7\right), 26.7\left(\mathrm{~d}, J_{C-P}=9.9\right), 56.8\left(\mathrm{~d}, J_{C-P}=5.0\right), 47.2\left(\mathrm{~d}, J_{C-P}=6.8\right), 116.8(\mathrm{~d}$, $\left.J_{C-P}=7.5\right), 121.7\left(\mathrm{q}, J_{C-F}=32.5\right), 124.9\left(\mathrm{q}, J_{C-F}=271.2\right), 126.0\left(\mathrm{q}, J_{C-F}=3.6\right), 145.6$.

$\mathbf{P h P}_{3}(\mathbf{d m a}) \cdot \mathrm{HBPh}_{4},\left(6 \cdot \mathrm{HBPh}_{4}\right)$. To a solution $2.3 \mathrm{mmol}(1.0 \mathrm{~g})$ of phosphine $\left[\left(\mathrm{Me}_{2} \mathrm{~N}\right)_{3} \mathrm{P}=\mathrm{N}-\right]_{2} \mathrm{PNMe}_{2}$ (synthesized according to the procedure Marchenko ${ }^{13}$ and liberated from its $\mathrm{HClO}_{4}$ salt by means of $30 \% \mathrm{KOMe}$ in $\mathrm{MeOH})$ in $5 \mathrm{~mL}$ of dry toluene at $70{ }^{\circ} \mathrm{C}$ a solution of $2.3 \mathrm{mmol}(0.27 \mathrm{~g})$ of phenyl azide ${ }^{7}$ in $4 \mathrm{~mL}$ of toluene was slowly added by syringe. The mixture was refluxed for $44 \mathrm{hr}$. The solvent was removed at reduced pressure and residue, brown viscous oil was dissolved in $\mathrm{MeOH}, 0.63 \mathrm{~g}$ of $\mathrm{NaBPh}_{4}$ in $5 \mathrm{~mL}$ of $\mathrm{MeOH}$ was added, precipitate was filtered off, washed with $\mathrm{MeOH}$ and recrystallized from 1:3 mixture of $\mathrm{MeCN} / \mathrm{MeOH}$ to give 0.6 g of beige crystals (mp 183.4-184.6 ${ }^{\circ} \mathrm{C}$, yield 31\%). Anal. Calcd. for $\mathrm{C}_{44} \mathrm{H}_{68} \mathrm{BN}_{10} \mathrm{P}_{3}: \mathrm{C}, 62.85 \% ; \mathrm{H}, 8.15 \% ; \mathrm{N}$, 16.66\%.Found : C, 63.07\%; H, 8.20\%; N; 16.65\%. ${ }^{1} \mathrm{H}$ NMR $(200 \mathrm{MHz}, \mathrm{MeCN}) \delta 2.58\left(\mathrm{~d}, 36 \mathrm{H}, J_{P-H}=10.2\right)$, $2.70\left(\mathrm{~d}, 6 \mathrm{H}, J_{P-H}=10.9\right), 5.6\left(\mathrm{~d}, 1 \mathrm{H}, J_{P-H}=8.5\right), 6.8-7.5(\mathrm{~m}, 15 \mathrm{H}), 7.2-7.3(\mathrm{~m}, 10 \mathrm{H}) .{ }^{13} \mathrm{C} \mathrm{NMR}(50 \mathrm{MHz}, \mathrm{MeCN})$ $\delta 37.2\left(\mathrm{~d}, J_{C-P}=6.0\right), 37.4\left(\mathrm{~d}, J_{C-P}=4.9\right), 118.2$ (under solvent peak), 121.3, 122.7, $126.5\left(J_{C-B}=2.8\right), 129.9$, $136.8,142.9,164.9\left(J_{C-B}=49.5\right)$. 
4-MeO- $\mathbf{C}_{6} \mathbf{H}_{4} \mathbf{P}_{3}(\mathbf{d m a}) \cdot \mathbf{H B P h}_{4},\left(\mathbf{5} \cdot \mathbf{H B P h}_{4}\right)($ Scheme 2$)$. A solution of $7.3 \mathrm{mmol}(1.09 \mathrm{~g})$ of p-methoxyphenyl azide ${ }^{11}$ in $4 \mathrm{~mL}$ of dry benzene was slowly added to a solution of $\mathrm{Me}_{2} \mathrm{NPCl}_{2}{ }^{6}$ in $3 \mathrm{~mL}$ of benzene. The mixture was warmed and benzene was distilled off. The residue was heated at $120{ }^{\circ} \mathrm{C}$ for $2 \mathrm{hr}$ and left then to cool. At 70 ${ }^{\circ} \mathrm{C} 5 \mathrm{~mL}$ of benzene was added, followed a solution of $24.1 \mathrm{mmol}(4.3 \mathrm{~g})$ of $\mathrm{HP}_{3}(\mathrm{dma})$ in $3 \mathrm{~mL}$ of benzene. Mixture was heated and benzene removed again. The residue was heated at $120{ }^{\circ} \mathrm{C}$ for $4 \mathrm{hr}$ and left then for a weekend. Dark brown viscous mass was taken up in $8 \mathrm{~mL} 70 \% \mathrm{EtNH}_{2}$ aq soln. A solution of $1.0 \mathrm{~g} \mathrm{NaBF}_{4}$ in minimum quantity of water was added and then some water up to turbidity. The solution was filtered and $\mathbf{5} \cdot \mathbf{H B F}_{4}$ salt was extracted twice with $\mathrm{CH}_{2} \mathrm{Cl}_{2}$, the extract was washed with water and concentrated (finally at reduced pressure). The residue was dissolved in $7 \mathrm{~mL}$ of $\mathrm{MeOH}$ and a solution of $2.5 \mathrm{~g} \mathrm{NaBPh}_{4}$ in $5 \mathrm{~mL}$ of $\mathrm{MeOH}$ was added. A light reddish-brown oil was fallen out. $\mathrm{MeOH}$ was separated and oil was dried at reduced pressure $\left(100{ }^{\circ} \mathrm{C} / 1 \mathrm{mmHg}\right)$. The residue was repeatedly extracted with hot $\mathrm{MeOH}$. By cooling, the methanolic solution was decanted from some fallen out drops of oil, crystals formed after two days were collected and washed with cold $\mathrm{MeOH}$. Recrystallization from $\mathrm{MeOH}$ gave $1.6 \mathrm{~g} \mathrm{5} \cdot \mathbf{H B P h}_{\mathbf{4}}\left(\mathrm{mp} 104.8-106.1{ }^{\circ} \mathrm{C}\right.$, yield $\left.25 \%\right)$. Anal. Calcd for $\mathrm{C}_{45} \mathrm{H}_{70} \mathrm{BM}_{10} \mathrm{OP}_{3}: \mathrm{C}, 62.07 \% ; \mathrm{H}, 8.10 \%$; N, 16.08\%. Found: C, 62.12\%; H, 8.11\%; N, $16.26 \%$. ${ }^{1} \mathrm{H}$ NMR $\left(200 \mathrm{MHz}, \mathrm{CDCl}_{3}\right) \delta 2.50\left(\mathrm{~d}, 36 \mathrm{H}, J_{P-H}=10.2\right), 2.66\left(\mathrm{~d}, 6 \mathrm{H}, J_{P-H}=11.2\right), 3.72(\mathrm{~s}, 3 \mathrm{H}), 4.41\left(\mathrm{~d}, 1 \mathrm{H}, J_{P-}\right.$ $\left.{ }_{H}=8.3\right), 6.67\left(\mathrm{~d}, 2 \mathrm{H}, J_{H-H}=9.1\right), 6.76\left(\mathrm{~d}, 2 \mathrm{H}, J_{H-H}=9.1\right), 6.89\left(\mathrm{t}, 4 \mathrm{H}, J_{H-H}=7.1\right), 7.04\left(\mathrm{t}, 8 \mathrm{H}, J_{H-H(a v)}=7.5\right), 7.42$ $(\mathrm{m}, 8 \mathrm{H}) .{ }^{13} \mathrm{C} \mathrm{NMR}\left(50 \mathrm{MHz}, \mathrm{CDCl}_{3}\right) \delta 36.9\left(\mathrm{~d}, J_{C-P}=5.5\right), 37.0\left(\mathrm{~d}, J_{C-P}=4.7\right), 55.7,114.8,119.0\left(\mathrm{~d}, J_{C-P}=6.7\right)$, $121.5,125.4\left(J_{C-B}=2.8\right), 133.9,136.4\left(J_{C-B}=1.5\right), 154.9,164.5\left(\mathrm{~J}_{B-C}=49.4\right)$.

$\left.\mathbf{P h P}_{\mathbf{3}}(\mathbf{p y r r}) \cdot \mathbf{H B F}_{\mathbf{4}}, \mathbf{( 4} \cdot \mathbf{H B F}_{\mathbf{4}}\right)($ Scheme 2). The same procedure was used as described for synthesis of $\mathbf{7} \cdot \mathbf{H B F}$. From $5 \mathrm{mmol}$ of pyrrPCl $2,5 \mathrm{mmol}$ of phenyl azide, ${ }^{7} 15.5 \mathrm{mmol}$ of $\mathrm{HP}_{1}$ (pyrr) and calculated quantity of $\mathrm{NaBF}_{4}$ $1.8 \mathrm{~g}$ of raw $\mathbf{4} \cdot \mathbf{H B F}_{\mathbf{4}}$ was collected. Recrystallization from EtOAc gave $0.6 \mathrm{~g}$ colorless crystals (mp 155.3-156.0 $\left.{ }^{\circ} \mathrm{C}\right)$. From the mother liquid after recrystallization from 2:5 mixture of Hex/EtOAc an additional $0.5 \mathrm{~g}$ crystals was obtained (yield 28\%). Anal. Calcd for $\mathrm{C}_{34} \mathrm{H}_{62} \mathrm{BF}_{4} \mathrm{~N}_{10} \mathrm{P}_{3}$ : C, 51.65\%; H, 7.91\%; N, 17.22\%. Found C, $51.83 \% ; \mathrm{H}, 7.89 \%$; N $17.63 \% .{ }^{1} \mathrm{H}$ NMR $\left(200 \mathrm{MHz}, \mathrm{CDCl}_{3}\right) \delta 1.82(\mathrm{~m}, 28 \mathrm{H}), 3.12(\mathrm{~m}, 28 \mathrm{H}), 5.17\left(\mathrm{~d}, 1 \mathrm{H}, J_{P-H}=\right.$ 
9.0), 6.8-6.9 (m, 3H), $7.18\left(\mathrm{t}, 2 \mathrm{H}, J_{H-H}=7.9\right) .{ }^{13} \mathrm{C} \mathrm{NMR}\left(50 \mathrm{MHz}, \mathrm{CDCl}_{3}\right) \delta 26.4\left(\mathrm{~d}, J_{C-P}=8.7\right), 26.7\left(\mathrm{~d}, J_{C-P}=\right.$ 9.9), $46.8\left(\mathrm{~d}, J_{C-P}=5.0\right), 47.2\left(\mathrm{~d}, J_{C-P}=6.6\right), 117.0\left(\mathrm{~d}, J_{C-P}=7.3\right), 120.3,129.0,141.8\left(\mathrm{~d}, J_{C-P}=1.3\right)$.

4-MeO- $\mathbf{C}_{6} \mathbf{H}_{4} \mathbf{P}_{3}$ (pyrr) $\cdot \mathbf{H B P h}_{4},(\mathbf{3} \cdot \mathbf{H B P h})$ (Scheme 2). To a solution of $5 \mathrm{mmol}(0.86 \mathrm{~g})$ of pyrrPCl $\mathrm{H}_{2}$ in $2 \mathrm{~mL}$ of dry toluene at room temperature a solution of $5 \mathrm{mmol}(0.74 \mathrm{~g})$ of p-methoxyphenyl azide ${ }^{11}$ in $2 \mathrm{~mL}$ toluene was added and the mixture was refluxed under Ar flow for $17 \mathrm{hr}$. To a slightly warm solution $16.5 \mathrm{mmol}(4.2 \mathrm{~g})$ of $\mathrm{HP}_{1}$ (pyrr) in $1 \mathrm{~mL}$ of toluene was added and the mixture was heated for $28 \mathrm{hr}$. The precipitate of $\mathrm{HP}_{1}(\mathrm{pyrr}) \cdot \mathrm{HCl}$ was filtered off, toluene was removed under reduced pressure to give a dark brown glassy mass. It was taken up with $6 \mathrm{~mL}$ of $\mathrm{MeOH}$ and a solution of $1.3 \mathrm{~g}$ of $\mathrm{NaBPh}_{4}$ in $6 \mathrm{~mL}$ of $\mathrm{MeOH}$ was added. A brown oil was settled down, which after washing with $\mathrm{MeOH}$ solidified soon to give a beige crystal mass. Recrystallization from 1:4 mixture of EtOAc/MeOH gave $1.1 \mathrm{~g}$ of lightly yellowish crystals of product (mp 108.8-110.0 ${ }^{\circ} \mathrm{C}$, yield 20\%). Anal. Calcd for $\mathrm{C}_{59} \mathrm{H}_{84} \mathrm{BN}_{10} \mathrm{P}_{3}: \mathrm{C}, 67.29 \% ; \mathrm{H}, 8.04 \% ; \mathrm{N}, 13.30 \%$. Found: C, 67.07\%; H, 8.06\%; N, $13.37 \%$. ${ }^{1} \mathrm{H}$ $\operatorname{NMR}\left(200 \mathrm{MHz}, \mathrm{CDCl}_{3}\right) \delta 1.77(\mathrm{~m}, 28 \mathrm{H}), 3.05(\mathrm{~m}, 28 \mathrm{H}), 3.73(\mathrm{~s}, 3 \mathrm{H}), 4.50\left(\mathrm{~d}, 1 \mathrm{H}, J_{P-H}=8.4\right), 6.68\left(\mathrm{~d}, 2 \mathrm{H}, J_{H-}\right.$ $\left.{ }_{H}=9.2\right), 6.75\left(\mathrm{~d}, 2 \mathrm{H}, J_{H-H}=9.2\right), 6.89\left(\mathrm{t}, 4 \mathrm{H}, J_{H-H}=7.1\right), 7.05\left(\mathrm{t}, 8 \mathrm{H}, J_{H-H(a v)}=7.5\right), 7.42(\mathrm{~m}, 8 \mathrm{H}) .{ }^{13} \mathrm{C} \mathrm{NMR}(50$ $\left.\mathrm{MHz}, \mathrm{CDCl}_{3}\right) \delta 26.4\left(\mathrm{~d}, J_{C-P}=8.7\right), 26.7\left(\mathrm{~d}, J_{C-P}=9.9\right), 46.8\left(\mathrm{~d}, J_{C-P}=5.0\right), 47.3\left(\mathrm{~d}, J_{C-P}=6.4\right), 55.8,114.7,118.1$ $\left(\mathrm{d}, J_{C-P}=6.8\right), 121.4,125.4\left(J_{C-B}=2.8\right), 134.5,136.4\left(J_{C-B}=1.5\right), 154.4,164.5\left(\mathrm{~J}_{B-C}=49.4\right)$.

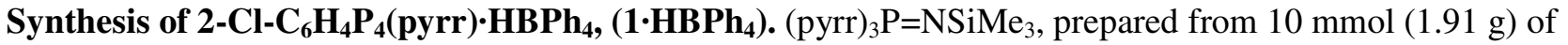
$\mathrm{Me}_{3} \mathrm{SiCCl}_{3}$ and $10 \mathrm{mmol}(2.56 \mathrm{~g})$ of $\mathrm{HP}_{1}$ (pyrr) as described by Marchenko et al ${ }^{14}$ for $\left(\mathrm{Et}_{2} \mathrm{~N}\right)_{3} \mathrm{P}=\mathrm{NSiMe}_{3}$, was dissolved in $2 \mathrm{~mL}$ of toluene and added to a solution of $9.3 \mathrm{mmol}(1.28 \mathrm{~g}) \mathrm{PCl}_{3}$ in $5 \mathrm{~mL}$ toluene. The mixture was stirred and after half an hour the volatile compounds were removed (finally at $60-70{ }^{\circ} \mathrm{C} / 5 \mathrm{mmHg}$ ). To the warm mixture of $7.5 \mathrm{mmol}(1.15 \mathrm{~g})$ 2-Cl-phenyl azide ${ }^{15,16}$ was added by means of syringe. The mixture was hold at $50-60{ }^{\circ} \mathrm{C}$ for $30 \mathrm{~min}$ after that $21.6 \mathrm{mmol}(5.5 \mathrm{~g})$ of $\mathrm{HP}_{1}$ (pyrr) was slowly added and mixture was left at $60{ }^{\circ} \mathrm{C}$ for 10 hours. The cool mixture was dissolved in THF. Precipitated $\mathrm{HP}_{1}(\mathrm{pyrr}) \cdot \mathrm{HCl}$ was filtered off and THF was removed (finally at $90{ }^{\circ} \mathrm{C} / 3 \mathrm{mmHg}$ ). Residue, dark brown sticky mass $\left(7.5 \mathrm{~g}\right.$ ) was dissolved in $60 \mathrm{ml} \mathrm{EtNH}_{2} 70$ $\%$ aq soln, $\mathrm{NaBF}_{4}$ solution in water was added to form $1 \cdot \mathrm{HBF}_{4}$ salt which was extracted with methylene chloride. Methylene chloride was removed, the residue was dissolved in $\mathrm{MeOH}$ and a solution of $\mathrm{NaBPh}_{4}$ in $\mathrm{MeOH}$ was 
added. A light brown oil was settled, which afterwards solidified to give $5.1 \mathrm{~g}$ of beige crystalline mass. It was washed with $63 \mathrm{ml}$ of boiling 1:1:7 mixture of EtOAc/MeCN/MeOH. The bright indissoluble crystalline mass was separated and repeatedly recrystallized from EtOAc/MeOH mixture to give $1.07 \mathrm{~g}$ of $\mathbf{1} \cdot \mathbf{H B P h}_{\mathbf{4}}$ salt of almost colorless needles (dec at $222{ }^{\circ} \mathrm{C}$, yield $12.0 \%$ ) Anal. Calcd. For $\mathrm{C}_{66} \mathrm{H}_{97} \mathrm{BClN}_{13} \mathrm{P}_{4}$ : C, 63.79\%; H, 7.87\%; N, 14.65\%. Found: C, 63.75\%; H, 7.95\%; N, 14.71\%. ${ }^{1} \mathrm{H}$ NMR (200 MHz, $\left.\mathrm{CDCl}_{3}\right) \delta 1.74(\mathrm{~m}, 48 \mathrm{H}), 3.10(\mathrm{~m}$, $48 \mathrm{H}), 5.85\left(\mathrm{~d}, 1 \mathrm{H}, J_{P-H}=9.8\right), 6.70\left(\mathrm{ddd}, 1 \mathrm{H}, J_{H-H}=1.6, J_{H-H}=7.4, J_{H-H}=7.9\right), 6.89\left(\mathrm{t}, 4 \mathrm{H}, J_{H-H}=7.1\right), 7.0-7.1(\mathrm{~m}$, $9 \mathrm{H}), 7.24\left(\mathrm{~m}, 1 \mathrm{H}, J_{H-H}=7.9\right), 7.43(\mathrm{~m}, 8 \mathrm{H}), 7.62\left(\mathrm{dd}, 1 \mathrm{H}, J_{H-H}=8.3\right) .{ }^{13} \mathrm{C} \mathrm{NMR}\left(50 \mathrm{MHz}, \mathrm{CDCl}_{3}\right) 26.3\left(\mathrm{~d}, J_{C-P}=\right.$ 8.8), $46.7\left(\mathrm{~d}, J_{C-P}=4.8\right), 117.8\left(\mathrm{~d}, J_{C-P}=3.2\right), 119.3,120.0\left(\mathrm{~d}, J_{C-P}=11.0\right), 121.4,125.5\left(J_{C-B}=2.8\right), 126.6,128.9$, $136.4\left(J_{C-B}=1.5\right), 140.0,164.5\left(J_{C-B}=49.5\right)$.

To get a free base sample of $\mathbf{1} \cdot \mathbf{H B P h}$ salt was converted by anion exchange resin Dowex Monosphere 550A (solvent and eluent 1:1 mixture of $\mathrm{MeCN}-\mathrm{MeOH}$ ) to $\mathbf{1} \cdot \mathbf{H C l}$ salt. This was dissolved in water, $\mathrm{NaBF}_{4}$ soln was added, $\mathbf{1} \cdot \mathbf{H B F}_{4}$ salt was collected, dried and liberated by means of MeOK as intimated above.

\section{${ }^{1} \mathrm{H}$ NMR and ${ }^{13} \mathrm{C}$ NMR data for liberated free $\mathbf{P}_{3^{-}}$and $\mathbf{P}_{4^{-}}$phosphazene bases.}

2-Cl- $\mathbf{C}_{\mathbf{6}} \mathbf{H}_{\mathbf{4}} \mathbf{P}_{\mathbf{4}}$ (pyrr), (1). ${ }^{1} \mathrm{H}$ NMR (200 MHz, THF) $\delta 1.8$ (m, overlapped by solvent, $\left.48 \mathrm{H}\right), 3.25$ (dt, 48H, $J_{H-H}=$ 6.6, $\left.J_{P-H}=3.9\right), 5.85(\mathrm{~m}, 1 \mathrm{H}), 6.58(\mathrm{~m}, 1 \mathrm{H}), 6.88(\mathrm{~m}, 1 \mathrm{H}), 7.39\left(\mathrm{~d}, 1 \mathrm{H}, J_{H-H}=8.3\right) .{ }^{13} \mathrm{C} \mathrm{NMR}(50 \mathrm{MHz}, \mathrm{THF})$ $\delta 27.1\left(\mathrm{~d}, J_{C-P}=8.4\right), 47.5\left(\mathrm{~d}, J_{C-P}=4.4\right), 108.9,122.2\left(\mathrm{~d}, J_{C-P}=15.5\right), 125.6,128.9,154.2$.

4-MeO-C $\mathbf{C}_{6} \mathbf{H}_{4} \mathbf{P}_{3}$ (pyrr), (3). ${ }^{1} \mathrm{H}$ NMR (200 MHz, THF) $\delta 1.8$ (m, overlapped by solvent, 28H), 3.17 (m, 28H), 3.7 (s, overlapped by solvent, $3 \mathrm{H}), 6.38\left(\mathrm{~d}, 2 \mathrm{H}, J_{H-H}=9.0\right), 6.62\left(\mathrm{~d}, 2 \mathrm{H}, J_{H-H}=9.0\right) .{ }^{13} \mathrm{C} \mathrm{NMR}(50 \mathrm{MHz}, \mathrm{THF})$ $\delta 27.0\left(\mathrm{~d}, J_{C-P}=8.2\right), 27.2\left(\mathrm{~d}, J_{C-P}=9.5\right), 47.5\left(\mathrm{~d}, J_{C-P}=4.4\right), 47.9\left(\mathrm{~d}, J_{C-P}=2.3\right), 56.1,114.5\left(\mathrm{~d}, J_{C-P}=2.0\right), 122.1$ $\left(\mathrm{d}, J_{C-P}=22.1\right), 149.4,151.6\left(\mathrm{~d}, J_{C-P}=2.1\right)$.

PhP $\mathbf{3}$ (pyrr), (4). ${ }^{1} \mathrm{H}$ NMR (200 MHz, THF) $\delta 1.8$ (m, overlapped by solvent, 28H), $3.2(\mathrm{~m}, 28 \mathrm{H}), 6.11(\mathrm{~m}, 1 \mathrm{H})$, $6.73(\mathrm{~m}, 4 \mathrm{H}) .{ }^{13} \mathrm{C}$ NMR $(50 \mathrm{MHz}, \mathrm{THF}) \delta 27.1\left(\mathrm{~d}, J_{C-P}=8.3\right), 27.2\left(\mathrm{~d}, J_{C-P}=9.5\right), 47.5\left(\mathrm{~d}, J_{C-P}=4.5\right), 47.8\left(\mathrm{~d}, J_{C-}\right.$ $\left.{ }_{P}=2.9\right), 112.2,122.4\left(\mathrm{~d}, J_{C-P}=22.1\right), 128.0\left(\mathrm{~d}, J_{C-P}=2.2\right), 157.0$. 
4-MeO-C $\mathbf{C}_{\mathbf{6}} \mathbf{H}_{\mathbf{4}} \mathbf{P}_{\mathbf{3}}$ (dma), (5). ${ }^{1} \mathrm{H}$ NMR $(200 \mathrm{MHz}, \mathrm{THF}) \delta 2.54\left(\mathrm{~d}, 36 \mathrm{H}, J_{P-H}=11.7\right), 2.64\left(\mathrm{~d}, 6 \mathrm{H}, J_{P-H}=10.1\right), 6.42$ $\left(\mathrm{d}, 2 \mathrm{H}, J_{H-H}=9.1\right), 6.67\left(\mathrm{~d}, 2 \mathrm{H}, J_{H-H}=9.1\right) .{ }^{13} \mathrm{C} \mathrm{NMR}(50 \mathrm{MHz}, \mathrm{THF}) \delta 37.8\left(\mathrm{~d}, J_{C-P}=3.9\right), 38.5,56.0,114.5(\mathrm{~d}$, $\left.J_{C-P}=1.6\right), 122.5\left(\mathrm{~d}, J_{C-P}=21.6\right), 148.8,150.9\left(\mathrm{~d}, J_{C-P}=1.9\right)$.

$\mathbf{P h P}_{\mathbf{3}}$ (dma), (6). ${ }^{1} \mathrm{H}$ NMR (200 MHz, THF) $\delta 2.56\left(\mathrm{~d}, J_{P-H}=11.7\right), 2.63\left(\mathrm{~d}, J_{P-H}=10.0\right), 6.13(\mathrm{~m}, 1 \mathrm{H}), 6.75(\mathrm{~m}$, 4H). ${ }^{13} \mathrm{C}$ NMR $(50 \mathrm{MHz}, \mathrm{THF}) \delta 37.8\left(\mathrm{~d}, J_{C-P}=3.8\right), 38.5,112.6,122.8,\left(\mathrm{~d}, J_{C-P}=21.9\right), 128.1\left(\mathrm{~d}, J_{C-P}=2.1\right)$, $156.8\left(\mathrm{~d}, J_{C-P}=2.0\right)$.

4- $\mathbf{C F}_{3}-\mathbf{C}_{6} \mathbf{H}_{4} \mathbf{P}_{3}$ (pyrr), (7). ${ }^{1} \mathrm{H}$ NMR (200 MHz, THF) $\delta 1.8$ (m, overlapped by solvent, $\left.28 \mathrm{H}\right), 3.1-3-2(\mathrm{~m}, 28 \mathrm{H})$, 3.7 (s, overlapped by solvent, $3 \mathrm{H}), 6.72\left(\mathrm{~d}, J_{H-H}=8.4\right), 6.98\left(\mathrm{~d}, J_{H-H}=8.4\right) .{ }^{13} \mathrm{C}$ NMR $(50 \mathrm{MHz}, \mathrm{THF}) \delta 27.10(\mathrm{~d}$, $\left.J_{C-P}=8.3\right), 27.14\left(\mathrm{~d}, J_{C-P}=9.5\right), 47.49\left(\mathrm{~d}, J_{C-P}=4.6\right), 47.70\left(\mathrm{~d}, J_{C-P}=2.9\right), 112.1\left(\mathrm{q}, J_{C-F}=31.5\right), 121.5\left(\mathrm{~d}, J_{C-P}=\right.$ $23.2), 125.3\left(\mathrm{dq}, J_{C-F}=3.6, J_{C-P}=3.0\right), 127.8\left(\mathrm{q}, J_{C-F}=268.8\right), 161.0\left(\mathrm{~d}, J_{C-P}=2.6\right)$.

4-CF $\mathbf{F}_{3}-\mathbf{C}_{6} \mathbf{H}_{\mathbf{4}} \mathbf{P}_{3}$ (dma), (10). ${ }^{1} \mathrm{H}$ NMR $(200 \mathrm{MHz}, \mathrm{THF}) \delta 2.54\left(\mathrm{~d}, 6 \mathrm{H}, J_{P-H}=11.8\right), 2.64\left(\mathrm{~d}, 36 \mathrm{H}, J_{P-H}=10.1\right), 6.78$ $\left(\mathrm{d}, 2 \mathrm{H}, J_{H-H}=8.6\right), 7.02\left(\mathrm{~d}, 2 \mathrm{H}, J_{H-H}=8.6\right) .{ }^{13} \mathrm{C} \mathrm{NMR}(50 \mathrm{MHz}, \mathrm{THF}) \delta 37.7\left(\mathrm{~d}, J_{C-P}=4.1\right), 38.2\left(\mathrm{~d}, J_{C-P}=0.9\right)$, $112.8\left(\mathrm{q}, J_{C-F}=31.5\right), 122.2\left(\mathrm{~d}, J_{C-P}=22.7\right), 125.4\left(\mathrm{dq}, J_{C-P}=2.6, J_{C-F}=3.6\right), 127.7\left(\mathrm{q}, J_{C-F}=269.1\right), 160.6\left(\mathrm{~d}, J_{C-P}=\right.$ $1.7)$.

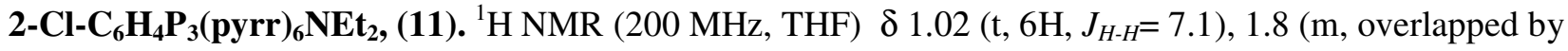
solvent, $24 \mathrm{H}), 3.1-3.2(\mathrm{~m}, 28 \mathrm{H}), 6.03\left(\mathrm{ddd}, 1 \mathrm{H}, J_{H-H}=1.5, J_{H-H}=7.1, J_{H-H}=7.9\right), 6.45(\mathrm{~m}, 1 \mathrm{H}), 6.92(\mathrm{~m}, 1 \mathrm{H}), 7.18$ $(\mathrm{m}, 1 \mathrm{H}) .{ }^{13} \mathrm{C}$ NMR $(50 \mathrm{MHz}, \mathrm{THF}) \delta 15.1\left(\mathrm{~d}, J_{C-P}=5.2\right), 27.0\left(\mathrm{~d}, J_{C-P}=8.7\right), 40.1\left(\mathrm{~d}, J_{C-P}=3.1\right), 47.4\left(\mathrm{~d}, J_{C-P}=\right.$ $4.4), 112.1,123.3\left(\mathrm{~d}, J_{C-P}=13.0\right), 125.9,126.8\left(\mathrm{~d}, J_{C-P}=33.2\right), 128.9\left(\mathrm{~d}, J_{C-P}=2.6\right), 153.3$.

2-Cl-C $\mathbf{C}_{\mathbf{6}} \mathbf{H}_{\mathbf{4}} \mathbf{P}_{\mathbf{3}}$ (dma) ${ }_{\mathbf{6}} \mathbf{N E t}_{\mathbf{2}}$, (15). ${ }^{1} \mathrm{H} \mathrm{NMR}(200 \mathrm{MHz}, \mathrm{THF}) \delta 1.06\left(\mathrm{t}, 6 \mathrm{H}, J_{H-H}=7.1\right), 2.66\left(\mathrm{~d}, 36 \mathrm{H}, J_{P-H}=10.1\right)$, $3.12\left(\mathrm{dq}, 4 \mathrm{H}, J_{P-H}=10.3, J_{H-H}=7.1\right), 6.08\left(\mathrm{ddd}, 1 \mathrm{H}, J_{H-H}=1.6, J_{H-H}=7.0, J_{H-H}=7.7\right), 6.68\left(\mathrm{ddd}, 1 \mathrm{H}, J_{H-H}=1.8, J_{H-}\right.$ $\left.{ }_{H}=7.0, J_{H-H}=8.3\right), 6.96\left(\mathrm{ddd}, 1 \mathrm{H}, J_{P-H}=2.6, J_{H-H}=1.8, J_{H-H}=7.7\right), 7.18\left(\mathrm{ddd}, 1 \mathrm{H}, J_{P-H}=1.1, J_{H-H}=1.6, J_{H-H}=8.3\right)$. ${ }^{13} \mathrm{C}$ NMR $(50 \mathrm{MHz}, \mathrm{THF}) \delta 15.3\left(\mathrm{~d}, J_{C-P}=5.1\right), 37.8\left(\mathrm{~d}, J_{C-P}=4.0\right), 41.1\left(\mathrm{~d}, J_{C-P}=3.3\right), 112.4,123.3\left(\mathrm{~d}, J_{C-P}=\right.$ $13.3), 127.1\left(\mathrm{~d}, J_{C-P}=33.7\right), 129.1\left(\mathrm{~d}, J_{C-P}=2.2\right), 153.1$. 
2,5-Cl $\mathbf{C l}_{\mathbf{2}}-\mathbf{C}_{\mathbf{6}} \mathbf{H}_{\mathbf{3}} \mathbf{P}_{\mathbf{3}}$ (pyrr) ${ }_{\mathbf{6}} \mathbf{N E t}_{\mathbf{2}}$, (20). ${ }^{1} \mathrm{H}$ NMR $(200 \mathrm{MHz}, \mathrm{THF}) \delta 1.05(\mathrm{t}, 6 \mathrm{H}, J H-H=7.1), \delta 1.8$ (m, overlapped by solvent, 24H), 3.1-3.3 (m, 28H), $6.03(\mathrm{dd}, 1 \mathrm{H}, J H-H=8.2, J H-H=2.6), 6.88(\mathrm{dd}, 1 \mathrm{H}, J H-H=8.2, J P-H=2.3)$, $7.26(\mathrm{dd}, 1 \mathrm{H}, J H-H=2.6, J P-H=1.0) .{ }^{13} \mathrm{C} \mathrm{NMR}(50 \mathrm{MHz}, \mathrm{THF}) \delta 15.1(\mathrm{~d}, J C-P=5.1), 27.1(\mathrm{~d}, J C-P=8.8)$, $41.0(\mathrm{~d}, J C-P=3.4), 47.4(\mathrm{~d}, J C-P=4.8), 111.3,122.3(\mathrm{~d}, J C-P=14.0), 125.2(\mathrm{~d}, J C-P=33.7), 129.2(\mathrm{~d}, J C-P=$ 1.2), $131.9(\mathrm{~d}, J C-P=0.9), 154.3$.

\section{References}

1. Part 2 of this series: Rodima, T.; Kaljurand, I.; Pihl, A.; Mäemets, V.; Leito, I.; Koppel, I. J. Org. Chem. 2002, 67, 1873-1881.

2. Appel, R.; Halstenberg, M. Angew. Chem. 1977, 89 (4), 268.

3. Dormoy, J.-R.; Castro, B. Tetrahedron Lett. 1979, 20, 3321-3322.

4. Marchenko, A. P.; Koidan, G. N.; Kudryavtsev, A. A. J. Gen. Chem. USSR, 1980, 50, 679-680.

5. Schwesinger, R.; Schlemper, H.; Hasenfratz, C.; Willaredt, J.; Dambacher, T.; Breuer, T.; Ottaway, C.; Fletschinger, M.; Boele, J.; Fritz, H.; Putzas, D.; Rotter, H. W.; Bordwell, F. G.; Satish, A. V.; Ji G.-Z.; Peters, E.-M.; Peters, K.; von Schnering, H. G.; Walz, L. Liebigs Ann. 1996, 1055-1081.

6. Nöth, H.; Vetter, H.-J. Chem. Ber. 1963, 96, 1109-1119.

7. Lindsay, R. O.; Allen, C. F. H. Organic Synthesis; Wiley: New York, 1955; Collect. Vol. III, p710.

8. Schwesinger, R.; Schlemper, H. Angew. Chem. Int. Ed. Engl. 1987, 26, 1167-1169.

9. Rodima, T.; Mäemets, V.; Koppel, I. A. J. Chem. Soc., Perkin Trans. 1, 2000, 2637-2644.

10. Zhmurova, I. N.; Kirsanov, A. V. J. Gen. Chem. USSR (Engl. Trans.) 1960, 30, 3018-3029.

11. Ugi, I.; Perlingen, H.; Behringer, L. Chem. Ber. 1958, 91, 2230-2335.

12. Burg, A. B.; Slota, P. J., Jr. J. Am. Chem. Soc. 1958, 80, 1107-1109. 
13. Marchenko, A. B.; Koidan, G. N.; Pinchuk, A. M.; Kirsanov, A. V. J. Gen. Chem. USSR, 1984, 54(8), 1774-1782.

14. Marchenko, A.P; Bespalko, G.K.; Koidan, G.N.; Pinchuk, A.M. J. Gen. Chem. USSR, 1983, 53(6), 1436-1437.

15. Spauschus, H.O.; Scott, J.M. J. Am. Chem. Soc. 1951, 73, 208-210.

16. Bullock, M.W.; Hand, J.J. J. Am. Chem. Soc. 1956, 78, 5854-5857.

17. Koppel, I. A.; Schwesinger, R.; Breuer, T.; Burk, P.; Herodes, K.; Koppel, I.; Leito, I. and Mishima, M. J. Phys. Chem. A, 2001, 105, 9575-9586. 
Table S1. Experimental results for UV-vis spectrophotometric measurements in THF.

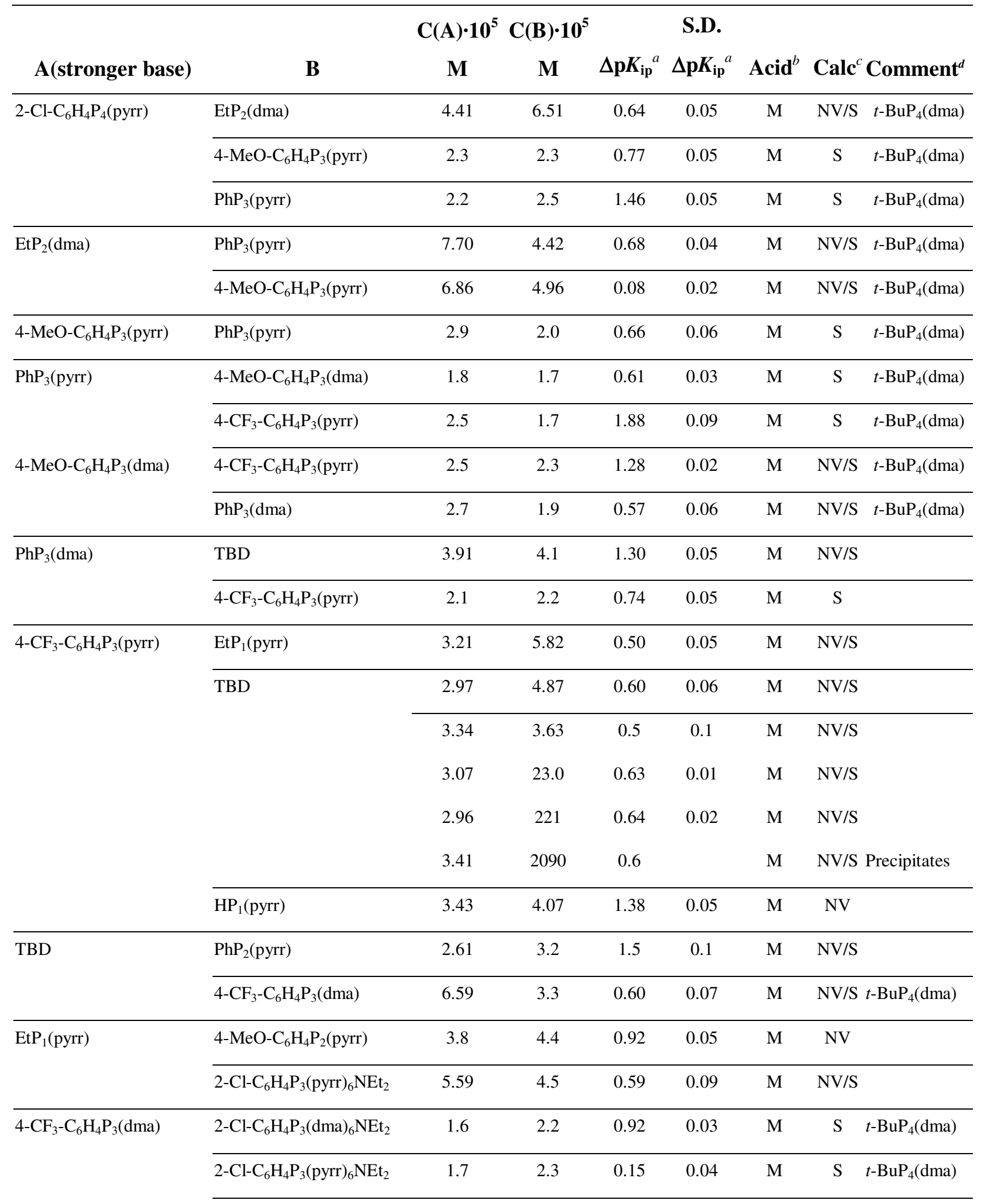




\begin{tabular}{|c|c|c|c|c|c|c|c|}
\hline & $\mathrm{MeP}_{1}(\mathrm{dma})$ & 3.57 & 4.40 & 0.49 & 0.08 & M & NV \\
\hline & $\mathrm{HP}_{1}($ pyrr $)$ & 2.91 & 3.91 & 0.26 & 0.07 & M & $\mathrm{NV} / \mathrm{S}$ \\
\hline \multirow[t]{3}{*}{$2-\mathrm{Cl}-\mathrm{C}_{6} \mathrm{H}_{4} \mathrm{P}_{3}(\text { pyrr })_{6} \mathrm{NEt}_{2}$} & $\mathrm{PhP}_{2}$ (pyrr) & 1.7 & 1.9 & 0.90 & 0.02 & $\mathrm{M}$ & S \\
\hline & $\mathrm{HP}_{1}$ (pyrr) & 4.43 & 3.92 & 0.34 & 0.07 & $\mathrm{M}$ & $\mathrm{NV} / \mathrm{S}$ \\
\hline & $\mathrm{MeP}_{1}(\mathrm{dma})$ & 3.87 & 4.11 & 0.40 & 0.07 & M & $\mathrm{NV} / \mathrm{S}$ \\
\hline \multirow[t]{6}{*}{ 4-MeO- $\mathrm{C}_{6} \mathrm{H}_{4} \mathrm{P}_{2}$ (pyrr) } & $\mathrm{PhP}_{2}$ (pyrr) & 1.9 & 2.8 & 0.63 & 0.02 & M & S \\
\hline & $\mathrm{t}-\mathrm{ButP}_{1}($ pyrr $)$ & 4.5 & 3.7 & 0.70 & 0.09 & M & NV \\
\hline & $2,5-\mathrm{Cl}-\mathrm{C}_{6} \mathrm{H}_{3} \mathrm{P}_{3}(\text { pyrr })_{6} \mathrm{NEt}_{2}$ & 3.2 & 1.9 & 1.35 & 0.1 & M & $S$ \\
\hline & $\mathrm{HP}_{1}$ (pyrr) & 4.47 & 3.74 & 0.13 & 0.04 & $\mathrm{M}$ & $\mathrm{NV} / \mathrm{S}$ \\
\hline & $\mathrm{HP}_{1}(\mathrm{dma})$ & 4.36 & 4.25 & 1.17 & 0.11 & $\mathrm{M}$ & $\mathrm{NV} / \mathrm{S}$ \\
\hline & $2-\mathrm{Cl}-\mathrm{C}_{6} \mathrm{H}_{4} \mathrm{P}_{3}(\mathrm{dma})_{6} \mathrm{NEt}_{2}$ & 2.3 & 2.2 & 0.5 & 0.14 & M & $\mathrm{S}$ \\
\hline $2-\mathrm{Cl}-\mathrm{C}_{6} \mathrm{H}_{4} \mathrm{P}_{3}(\mathrm{dma})_{6} \mathrm{NEt}_{2}$ & $2,5-\mathrm{Cl}-\mathrm{C}_{6} \mathrm{H}_{3} \mathrm{P}_{3}(\text { pyrr })_{6} \mathrm{NEt}_{2}$ & 2.4 & 1.8 & 1.10 & 0.02 & $\mathrm{M}$ & $\mathrm{S}$ \\
\hline \multirow[t]{4}{*}{$\mathrm{PhP}_{2}$ (pyrr) } & MTBD & 3.6 & 3.5 & 1.7 & 0.1 & $\mathrm{M}$ & $\mathrm{NV} / \mathrm{S}$ \\
\hline & t-ButP $P_{1}$ (pyrr) & 3.0 & 4.5 & 0.03 & 0.02 & $\mathrm{M}$ & NV \\
\hline & $\mathrm{HP}_{1}(\mathrm{dma})$ & 3.20 & 3.87 & 0.49 & 0.09 & M & $\mathrm{NV} / \mathrm{S}$ \\
\hline & 2,5-Cl- $\mathrm{C}_{6} \mathrm{H}_{3} \mathrm{P}_{3}(\text { pyrr })_{6} \mathrm{NEt}_{2}$ & 2.0 & 2.1 & 0.85 & 0.09 & $\mathrm{M}$ & S \\
\hline $\mathrm{t}-\mathrm{ButP}_{1}(\mathrm{pyrr})$ & $\mathrm{PhP}_{2}(\mathrm{dma})$ & 5.88 & 3.96 & 0.97 & 0.06 & M & $\mathrm{NV} / \mathrm{S}$ \\
\hline $\mathrm{HP}_{1}(\mathrm{dma})$ & $2,5-\mathrm{Cl}-\mathrm{C}_{6} \mathrm{H}_{3} \mathrm{P}_{3}(\text { pyrr })_{6} \mathrm{NEt}_{2}$ & 3.98 & 3.91 & 0.36 & 0.07 & M & $\mathrm{NV} / \mathrm{S}$ \\
\hline \multirow[t]{3}{*}{$\mathrm{PhP}_{2}(\mathrm{dma})$} & $\mathrm{t}-\mathrm{ButP}_{1}(\mathrm{dma})$ & 4.17 & 6.85 & 0.43 & 0.06 & M & $\mathrm{NV} / \mathrm{S}$ \\
\hline & MTBD & 3.96 & 6.69 & 0.76 & 0.02 & M & $\mathrm{NV} / \mathrm{S}$ \\
\hline & 2,5-Cl- $\mathrm{C}_{6} \mathrm{H}_{3} \mathrm{P}_{3}(\text { pyrr })_{6} \mathrm{NEt}_{2}$ & 2.2 & 1.9 & 0.07 & 0.08 & $\mathrm{M}$ & $\mathrm{S}$ \\
\hline \multirow[t]{2}{*}{$2,5-\mathrm{Cl}-\mathrm{C}_{6} \mathrm{H}_{3} \mathrm{P}_{3}(\mathrm{pyrr})_{6} \mathrm{NEt}_{2}$} & $\mathrm{DBU}$ & 3.85 & 3.81 & 1.10 & 0.10 & $\mathrm{M}$ & NV \\
\hline & MTBD & 4.1 & 4.34 & 0.55 & 0.09 & $\mathrm{M}$ & $\mathrm{NV} / \mathrm{S}$ \\
\hline 4-MeO- $\mathrm{C}_{6} \mathrm{H}_{4} \mathrm{P}_{1}$ (pyrr) & $\mathrm{PhP}_{1}(\mathrm{dma})_{2} \mathrm{Me}$ & 2.3 & 2.1 & 1.48 & 0.02 & $\mathrm{M}$ & S \\
\hline \multirow[t]{2}{*}{$\mathrm{PhP}_{1}(\mathrm{dma})_{2} \mathrm{Me}$} & PhTMG & 2.2 & 2.0 & 0.51 & 0.02 & $\mathrm{M}$ & $\mathrm{S}$ \\
\hline & $4-\mathrm{CF}_{3}-\mathrm{C}_{6} \mathrm{H}_{4} \mathrm{P}_{1}$ (pyrr) & 2.1 & 1.7 & 0.96 & 0.02 & $\mathrm{M}$ & $\mathrm{S}$ \\
\hline
\end{tabular}

${ }^{a} \Delta \mathrm{p} K_{\mathrm{ip}}=\mathrm{p} K_{\mathrm{ip}}(\mathrm{A})-\mathrm{p} K_{\mathrm{ip}}(\mathrm{B})$, S.D. $\Delta \mathrm{p} K_{\mathrm{ip}}$ is standard deviation of mean $\Delta \mathrm{p} K_{\mathrm{ip}}-\mathrm{s}$ obtained from titration experiments. ${ }^{b}$ Abbreviation of the acid titrated with: $\mathrm{T}=\mathrm{CF}_{3} \mathrm{SO}_{3} \mathrm{H}, \mathrm{M}=\mathrm{CH}_{3} \mathrm{SO}_{3} \mathrm{H}$. ${ }^{c}$ Calculation method: NV - one base is "non-visible", $\Delta \mathrm{p} K_{\mathrm{ip}}$ calculated on molar basis, $\mathrm{S}$ - calculated from UV-vis 
spectra. ${ }^{d}$ Comments - " $t$ - $\mathrm{BuP}_{4}(\mathrm{dma})$ " means that this phosphazene base was used as basic titrant, "precipitates" means that on titrating with an acid, extensive salt precipitation started when about $15 \%$ of TBD was neutralized and thus the value of $\Delta \mathrm{p} K_{\text {ip }}$ given in the $5^{\text {th }}$ column is an estimated value. 
Figures S2. ${ }^{13}$ C-NMR spectra of selected compounds

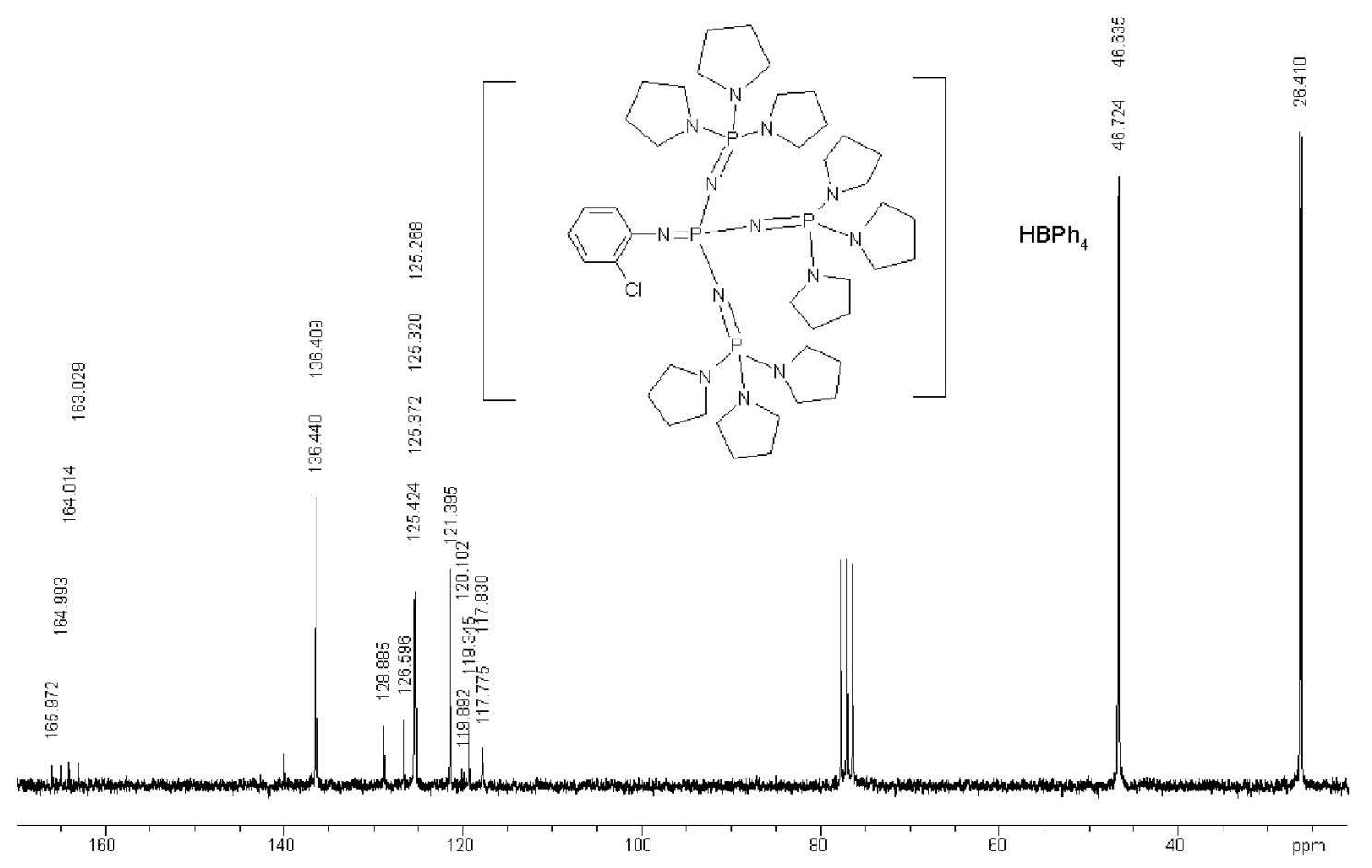

Figure S2-1. 1· $\mathrm{HBPh}_{4}$

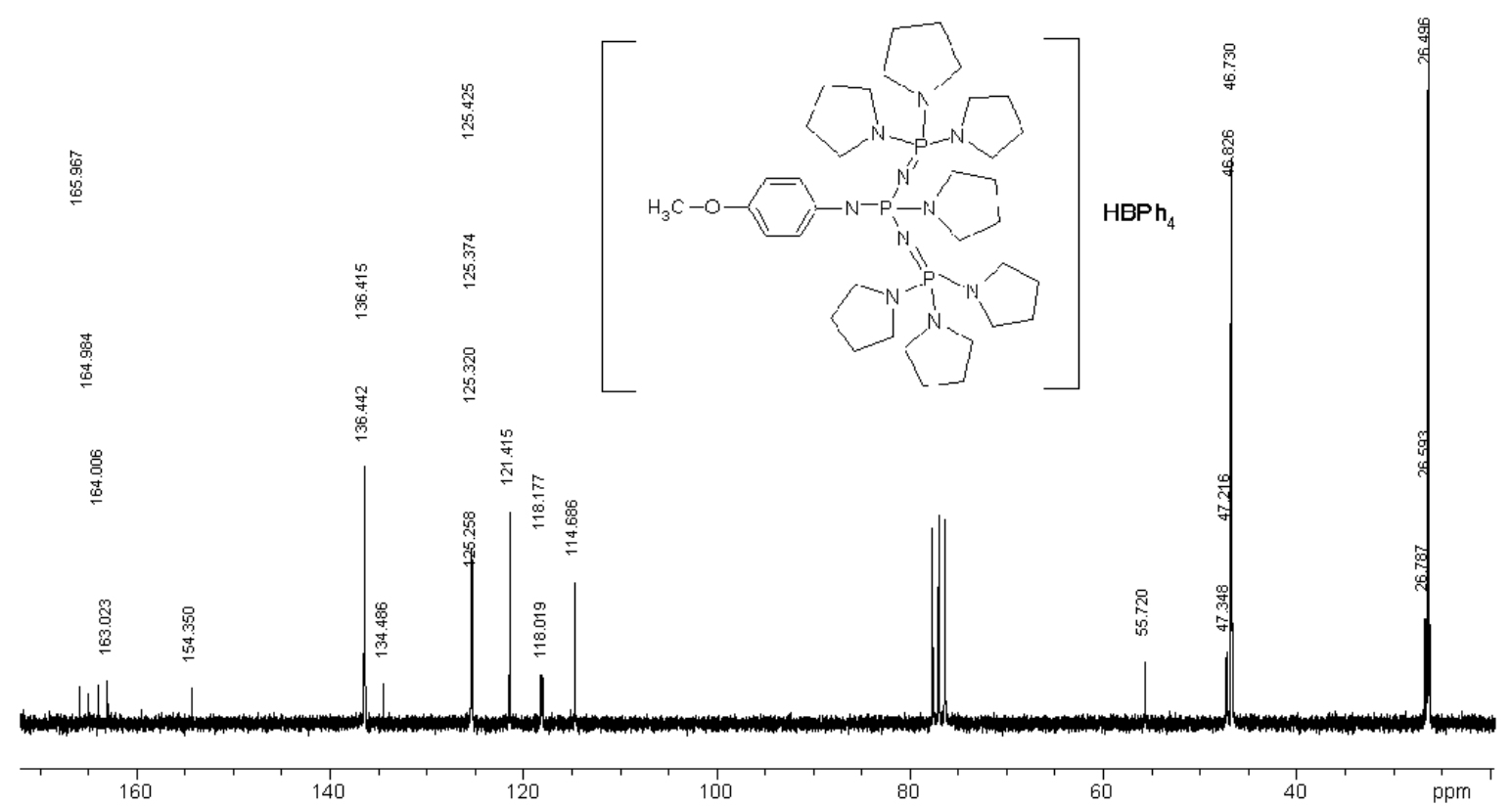

Figure S2-2. 3. $\mathrm{HBPh}_{4}$ 


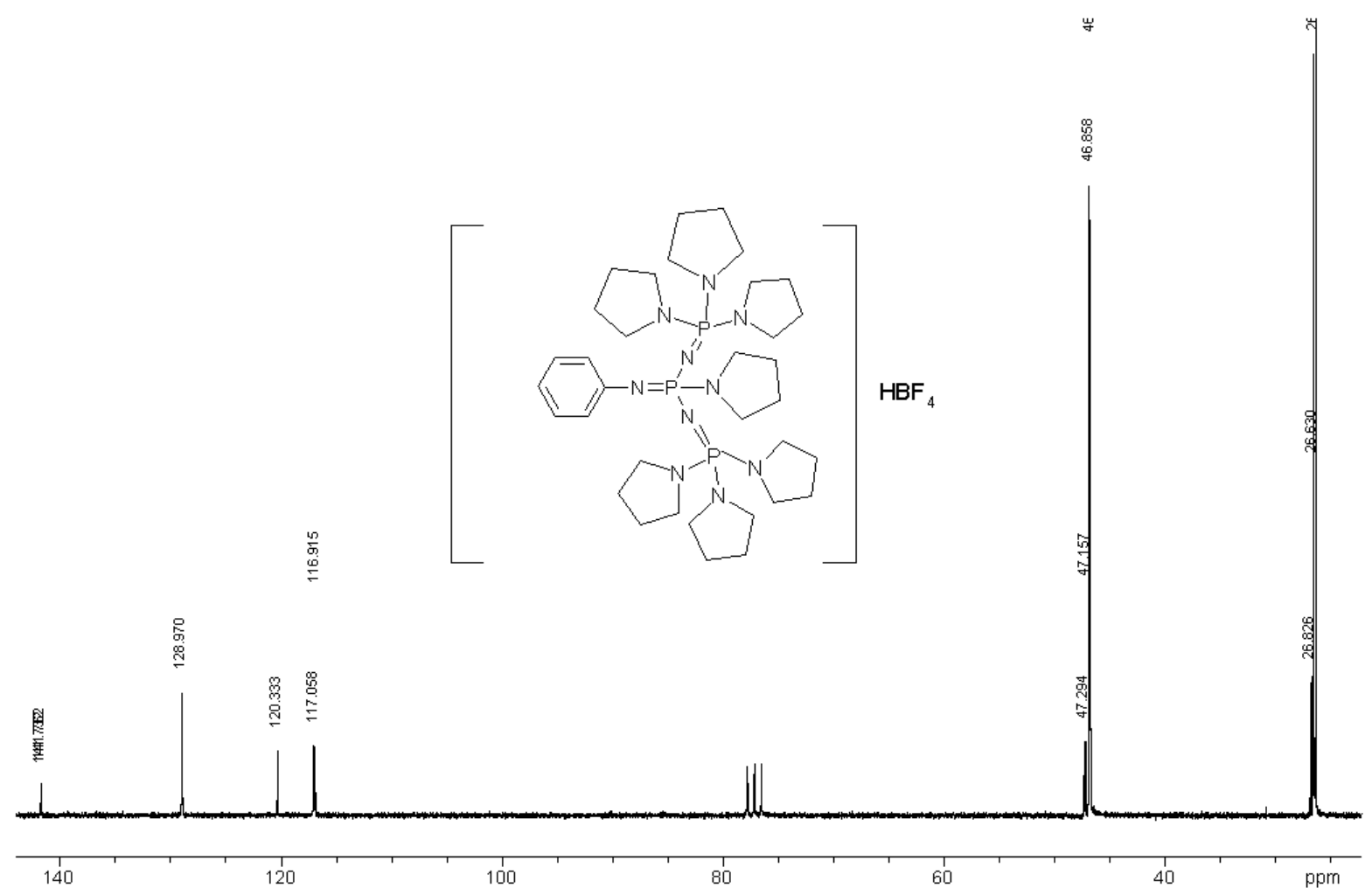

Figure S2-3. $4 \cdot \mathrm{HBF}_{4}$

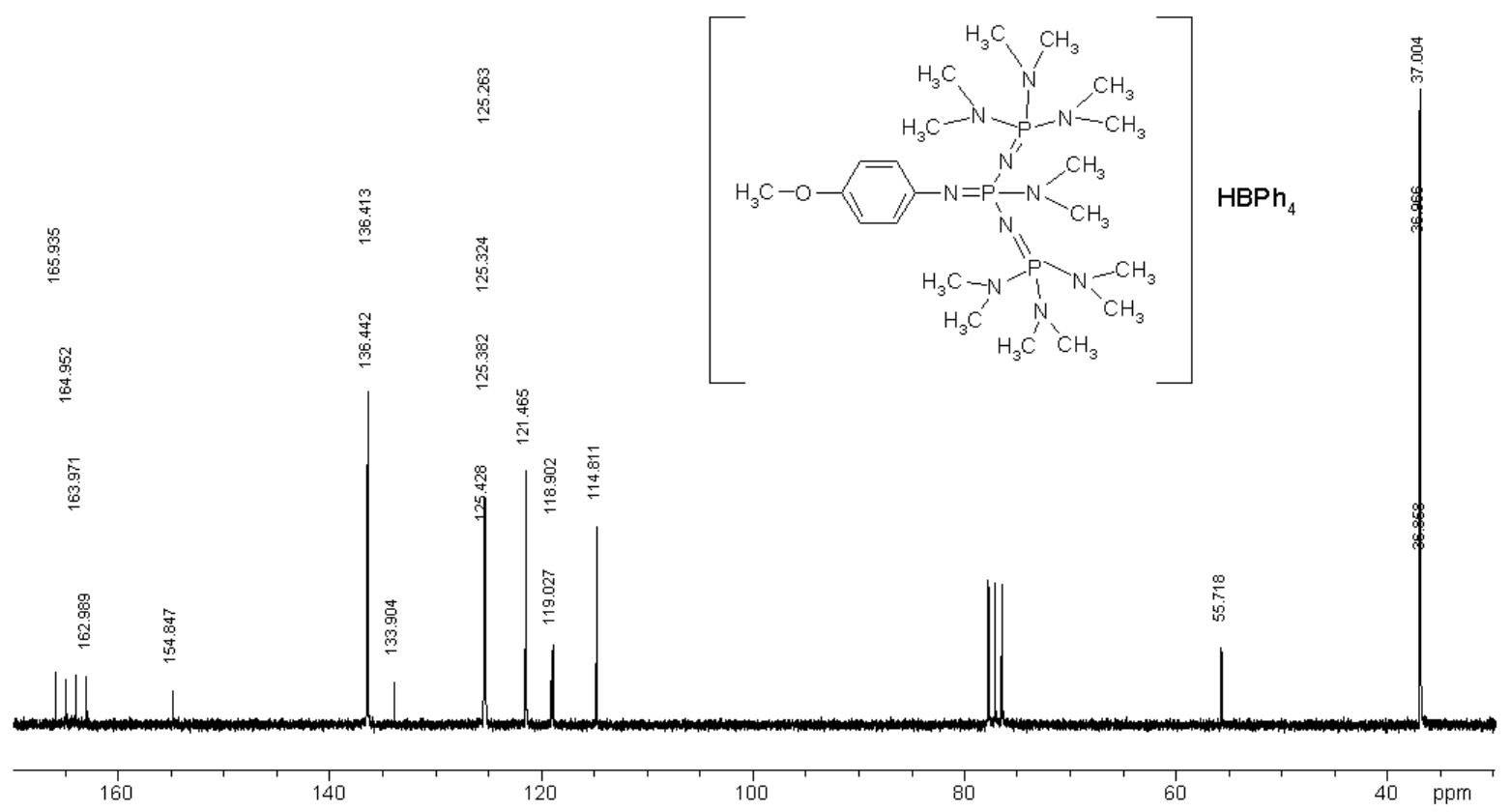

Figure S2-4. 5·HBPh 


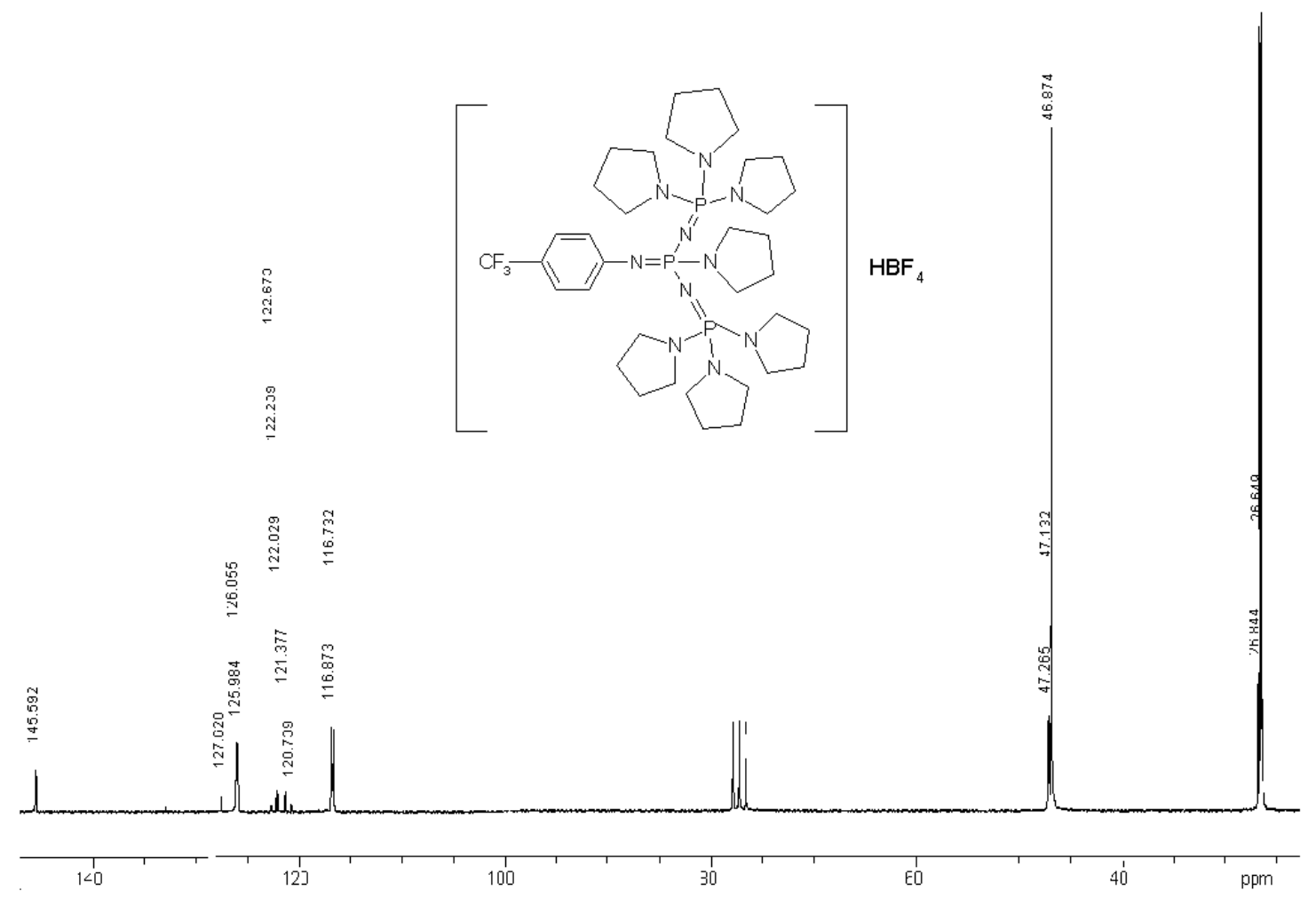

Figure S2-5. 7. $\mathrm{HBF}_{4}$

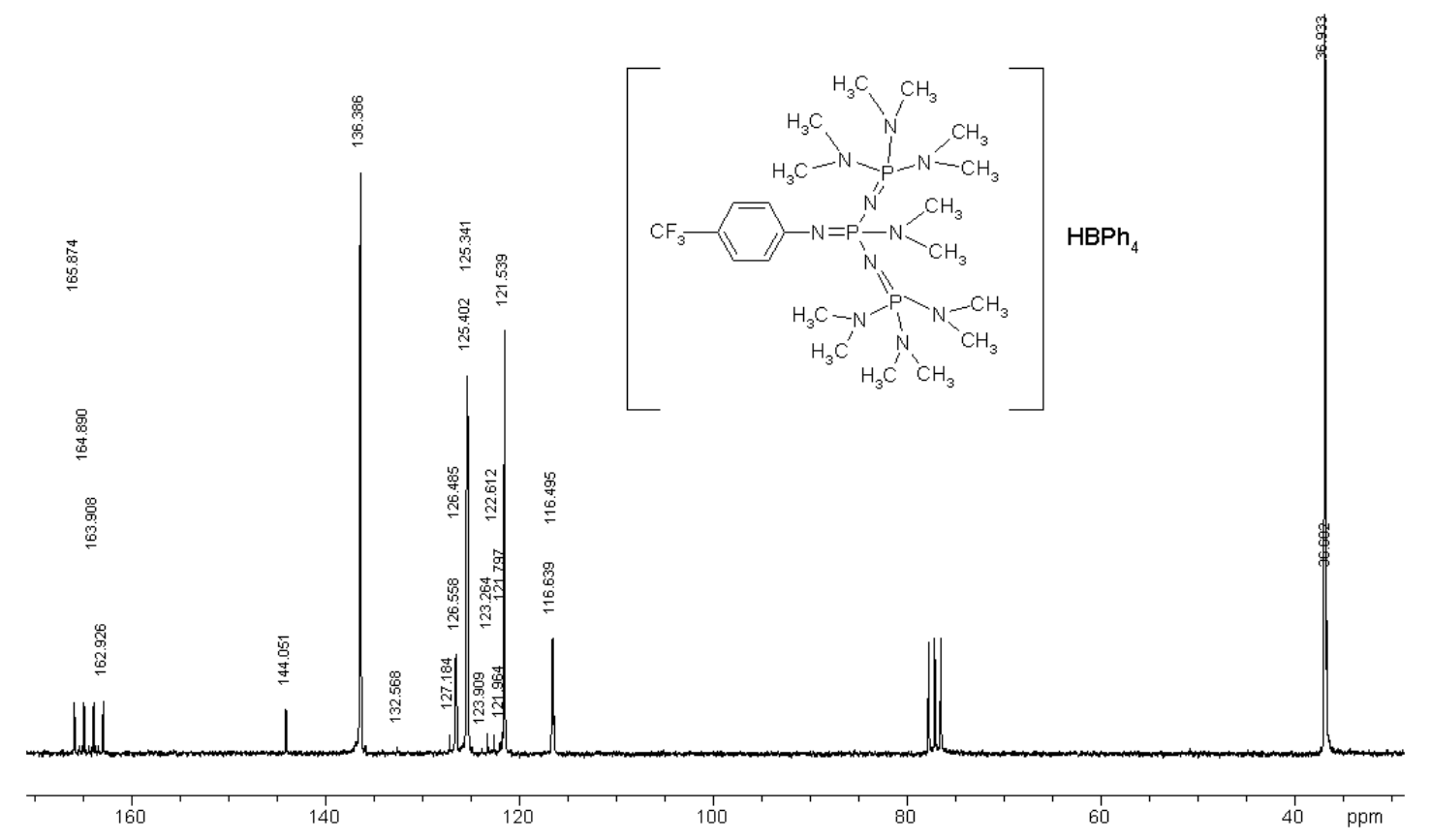

Figure S2-6. $10 \cdot \mathrm{HBPh}_{4}$ 


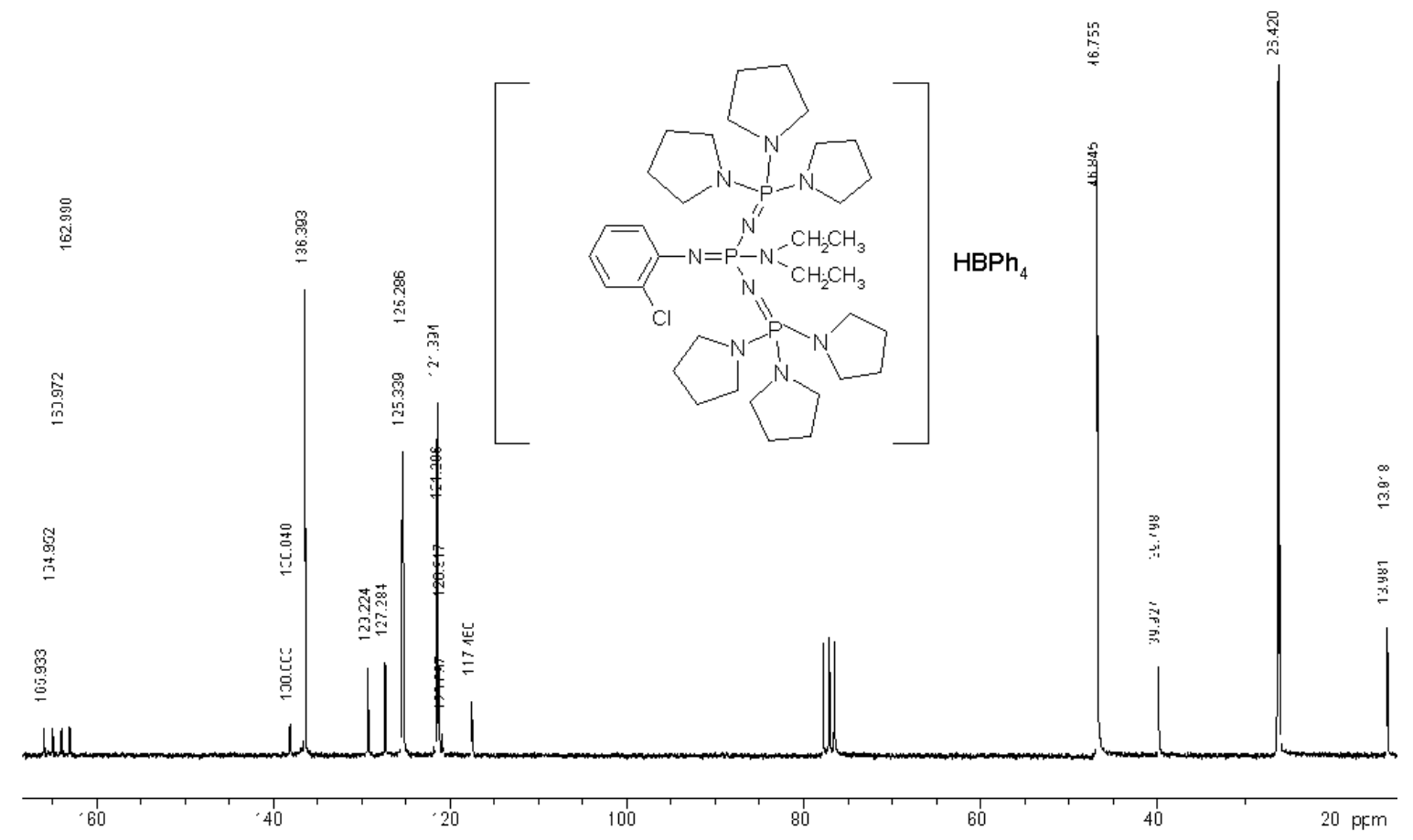

Figure S2-7. $11 \cdot \mathrm{HBPh}_{4}$

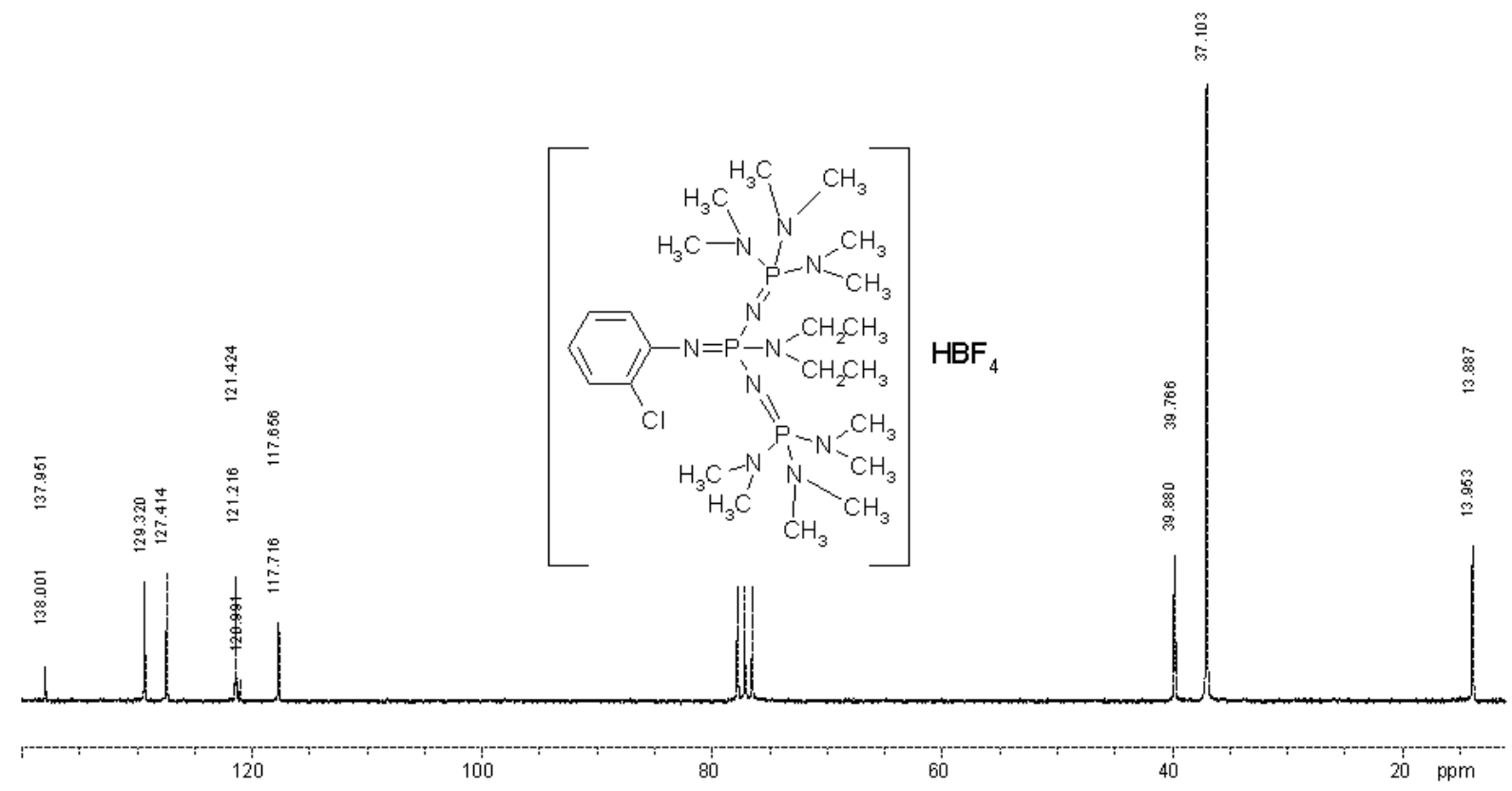

Figure S2-8. $15 \cdot \mathrm{HBF}_{4}$ 


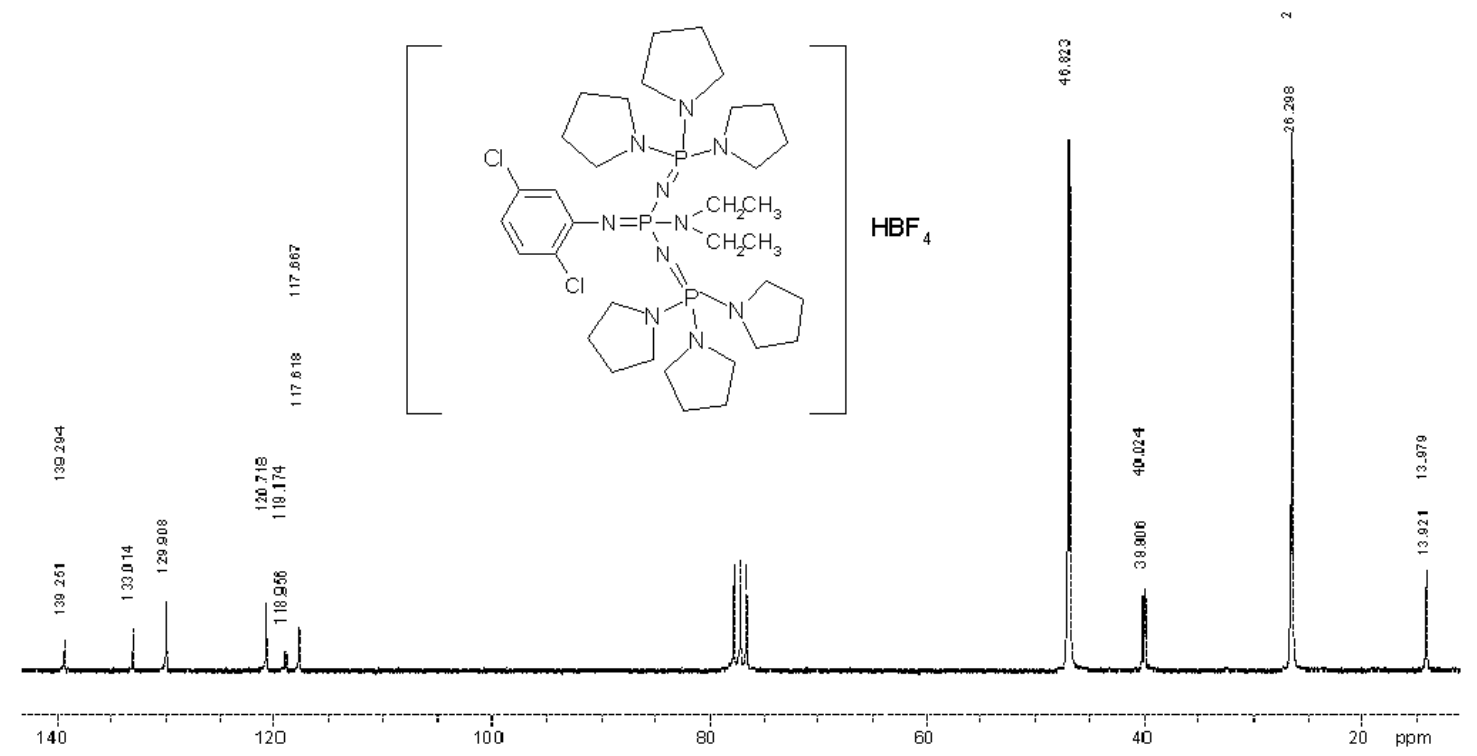

Figure S2-9. $20 \cdot \mathrm{HBF}_{4}$

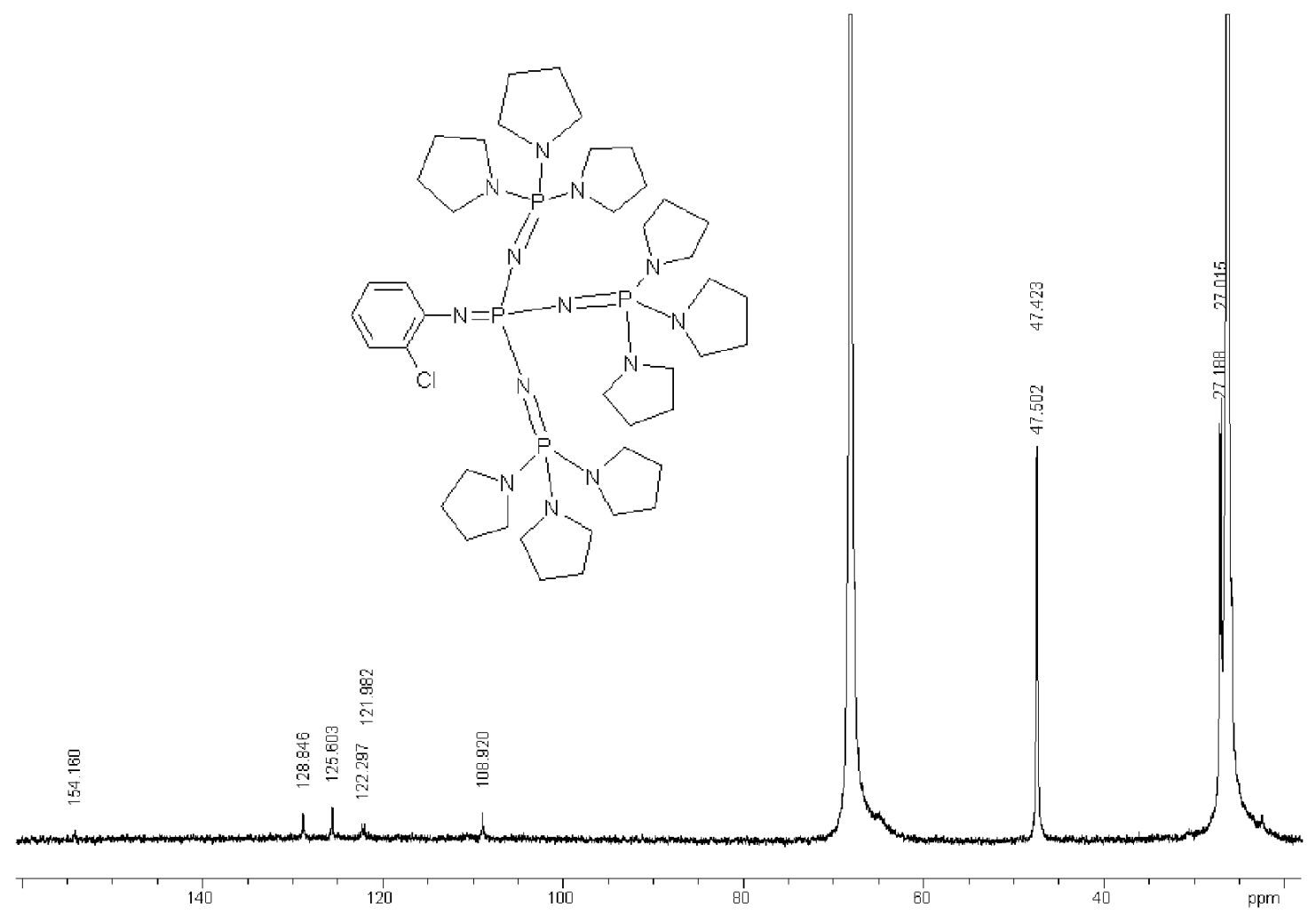

Figure S2-10. 1 


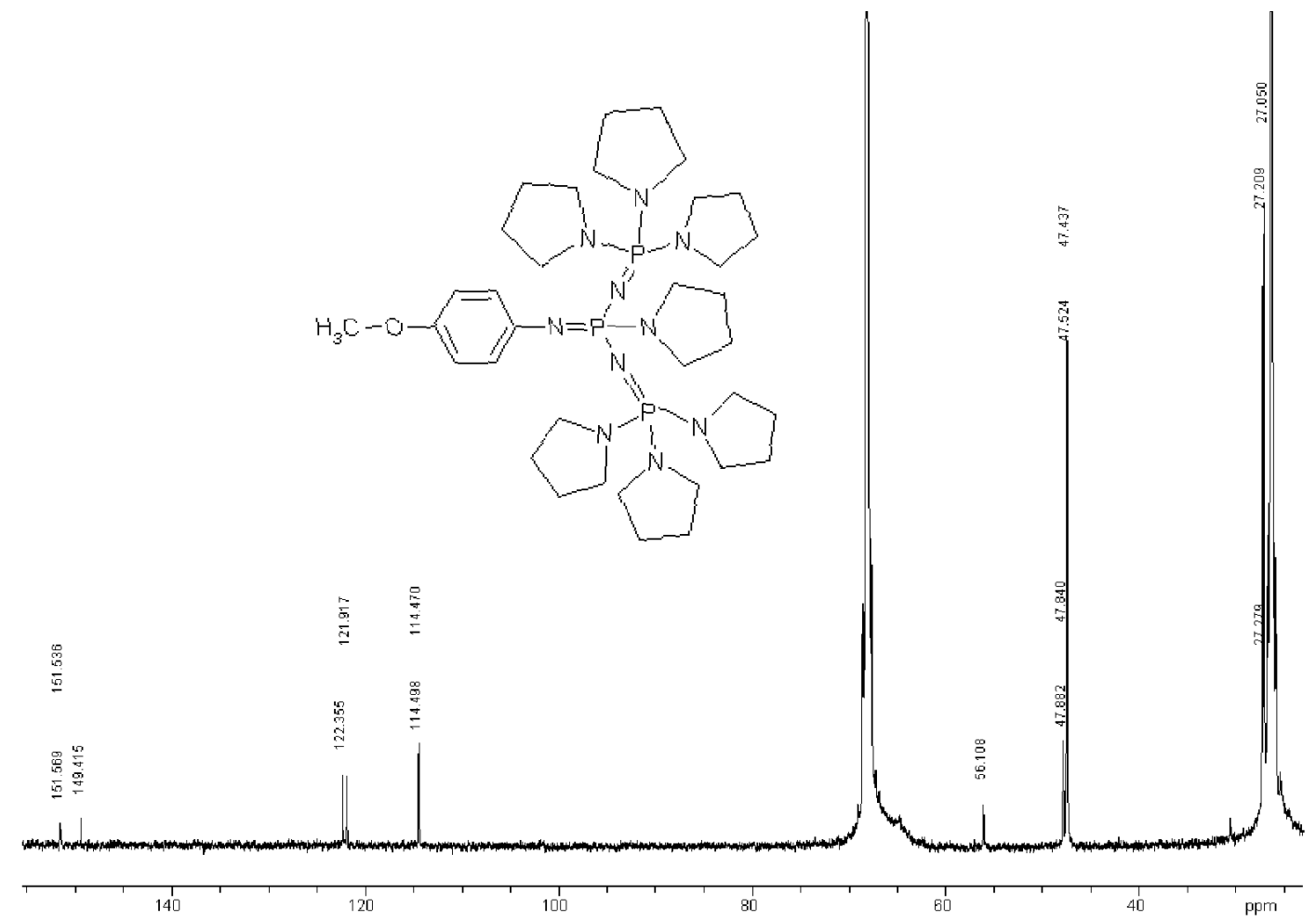

Figure S2-11. 3

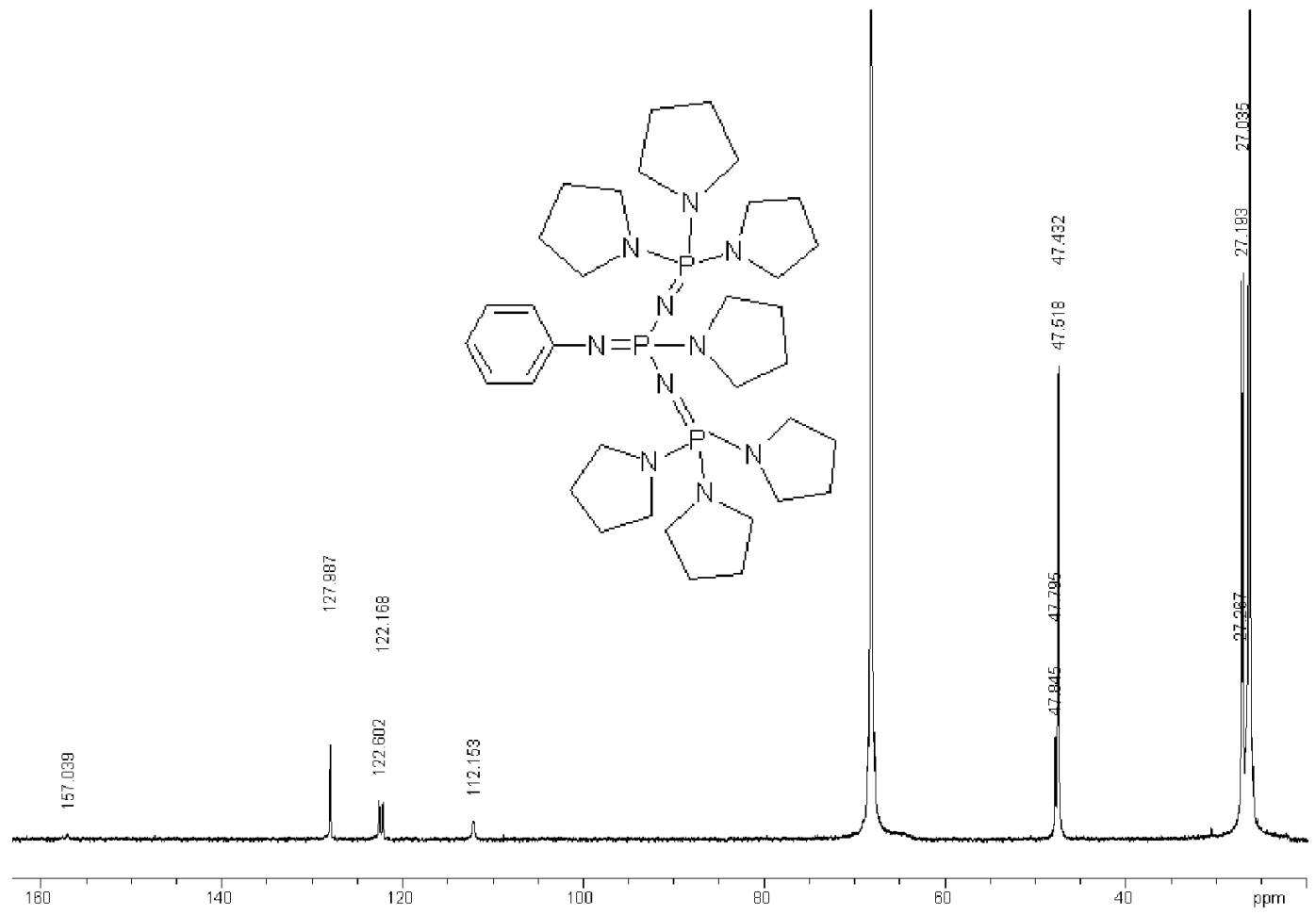

Figure S2-12. 4 


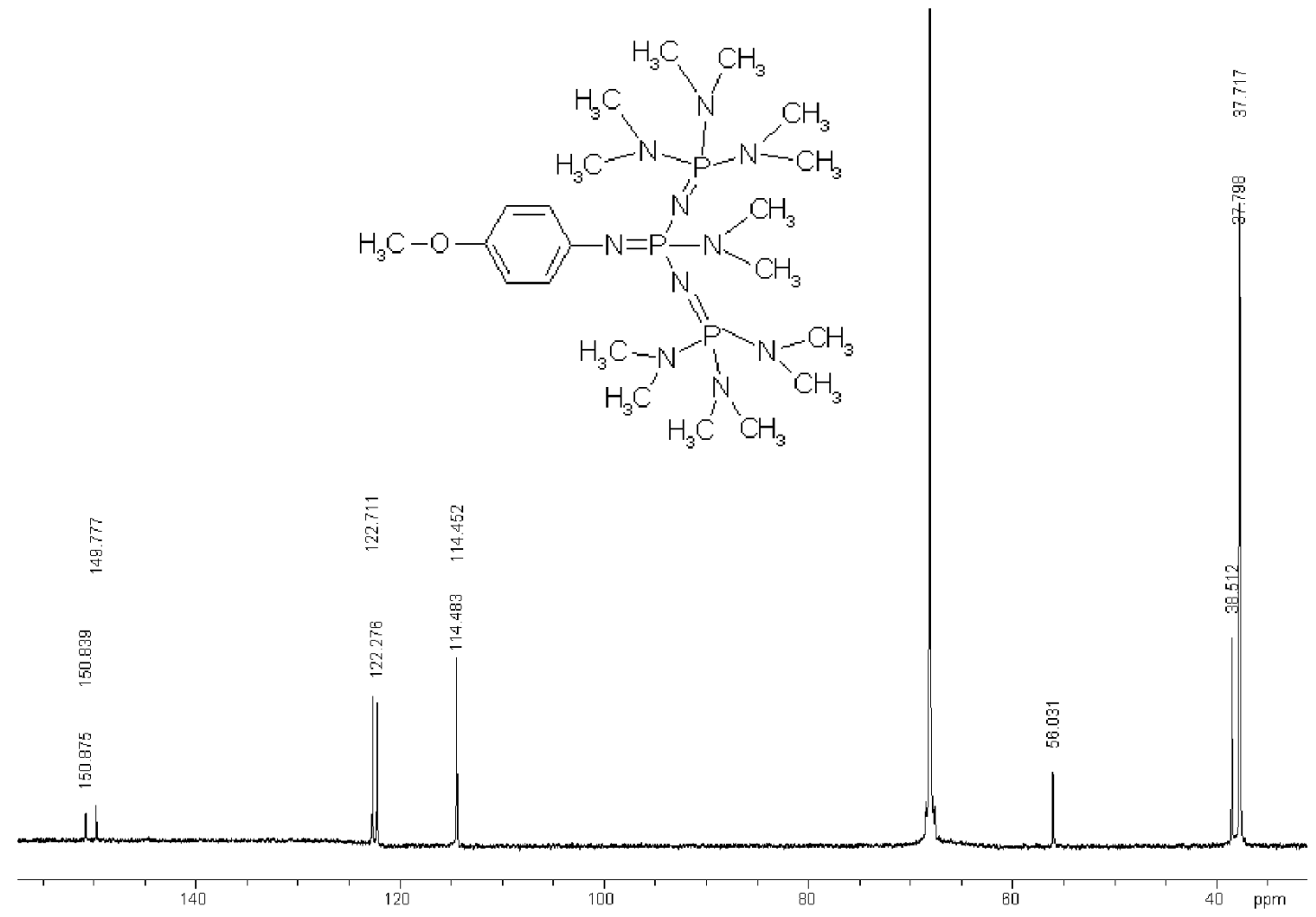

Figure S2-13. 5

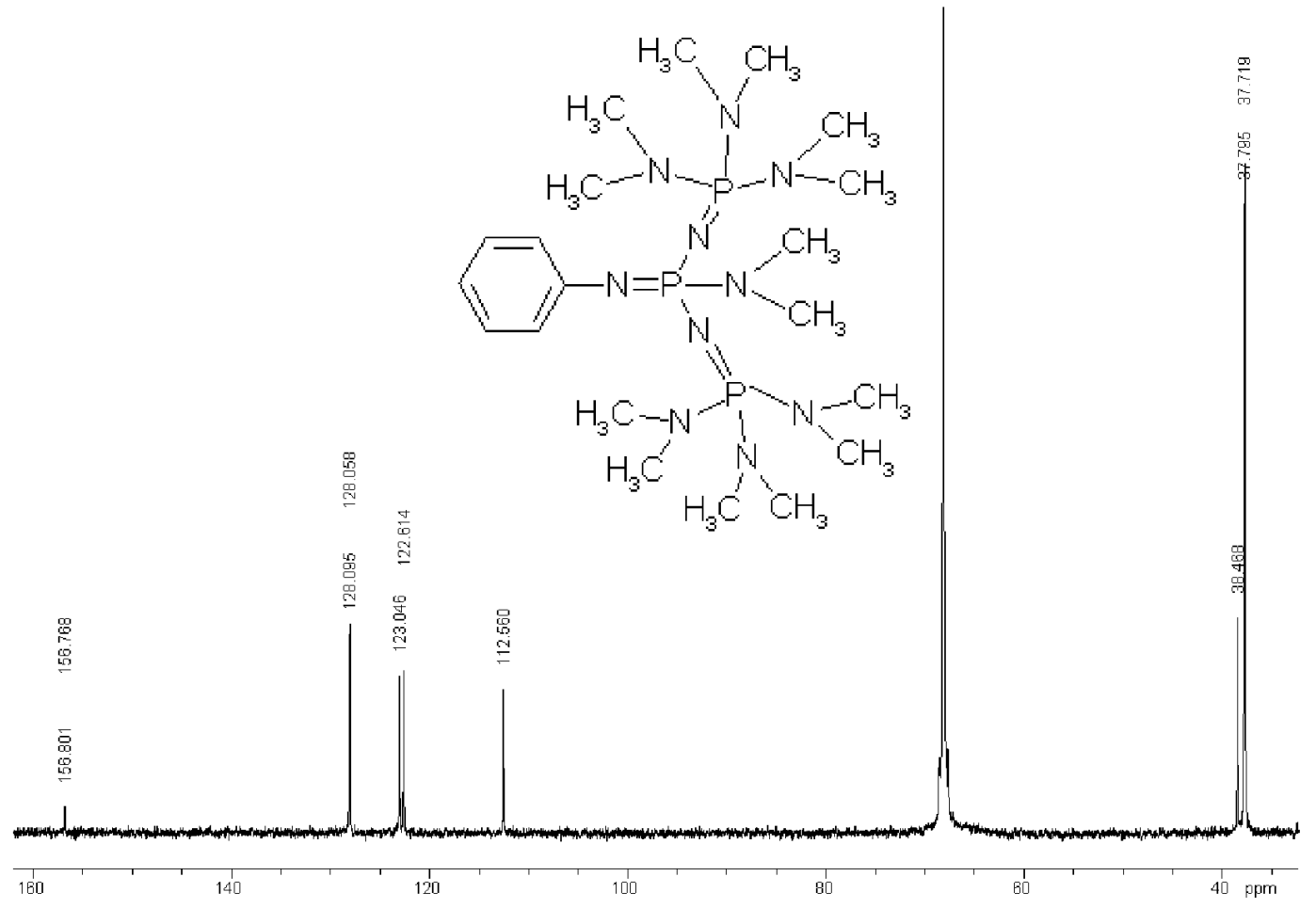

Figure S2-14. 6 


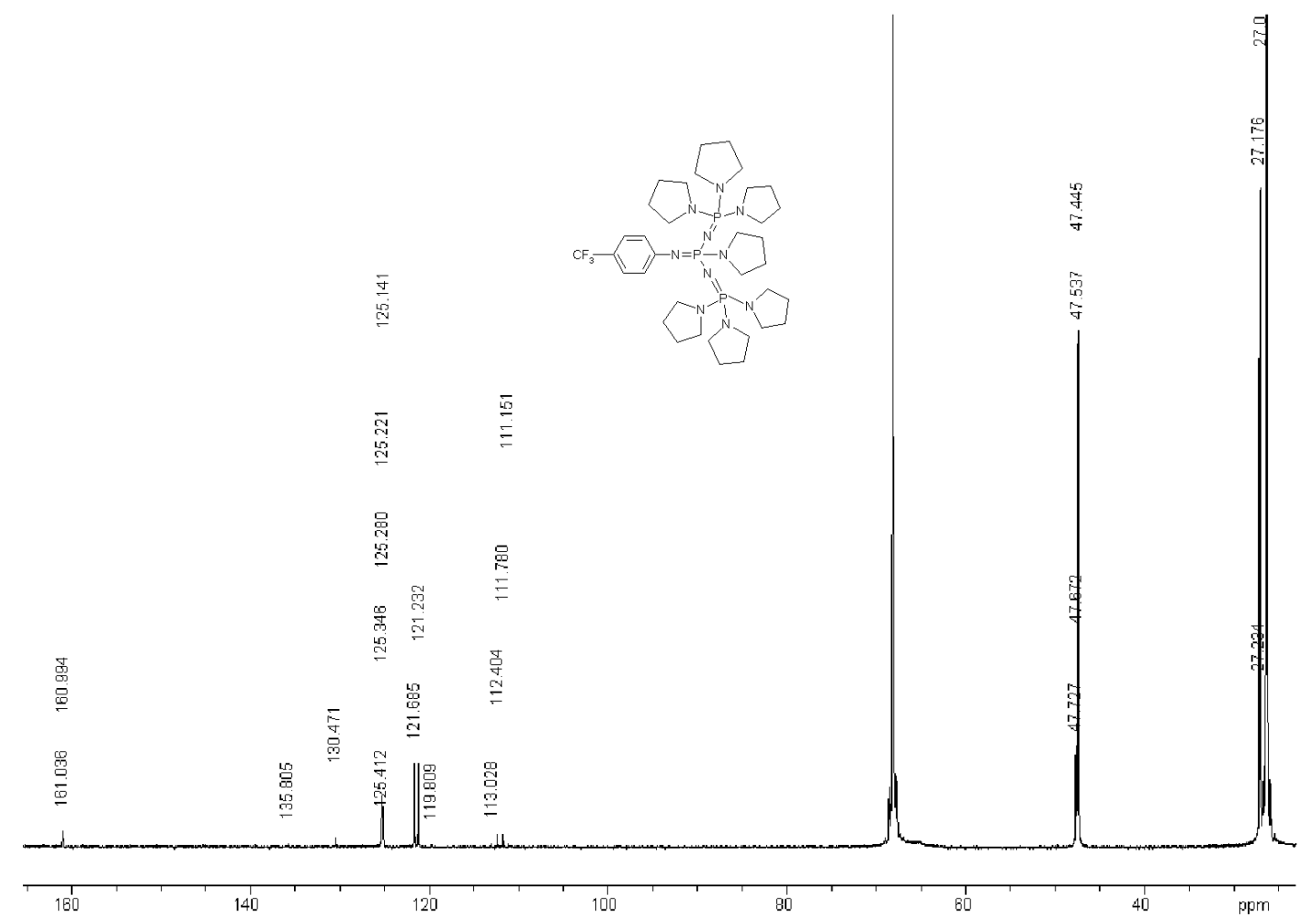

Figure S2-15. 7

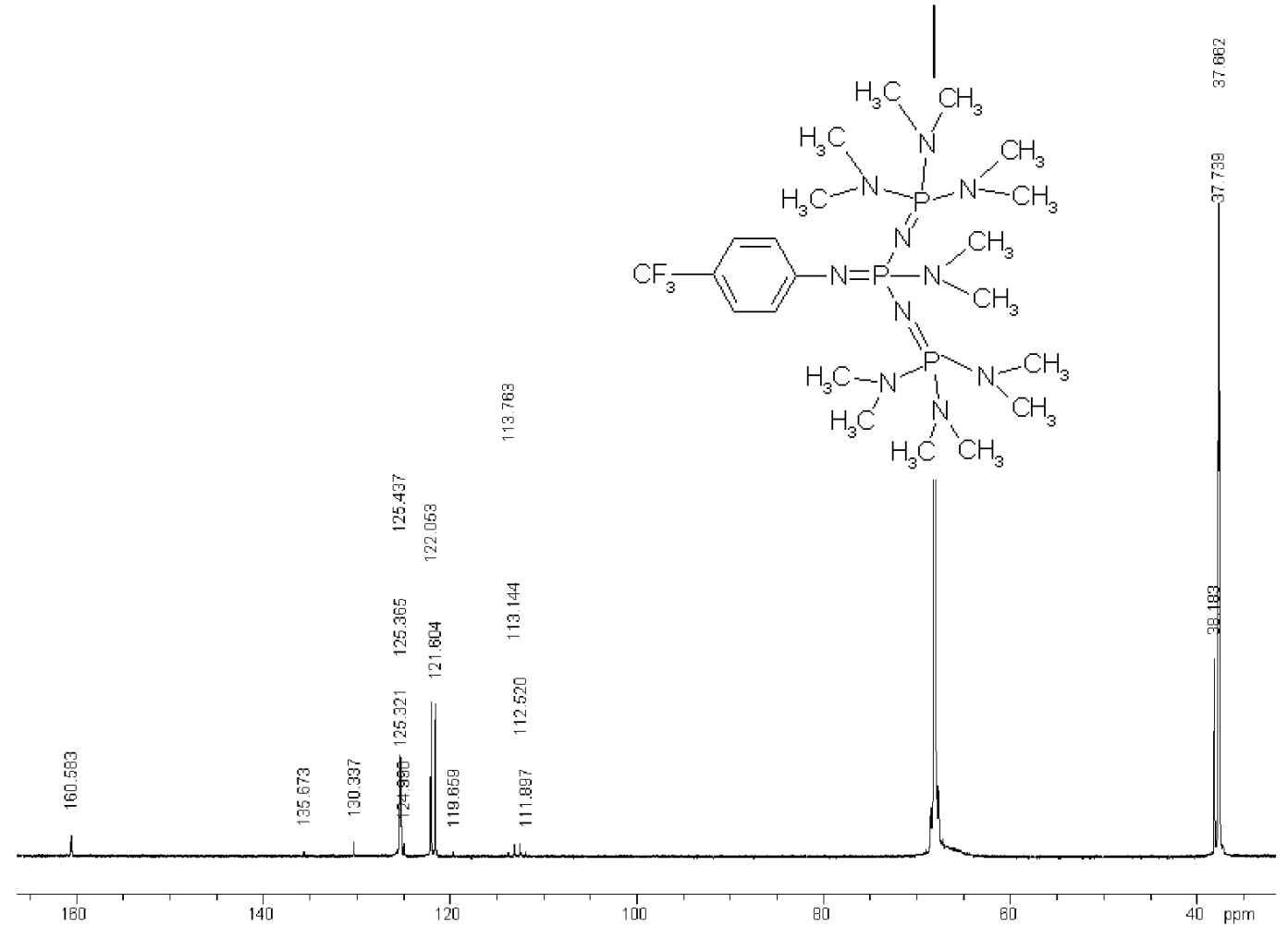

Figure S2-16. 10 


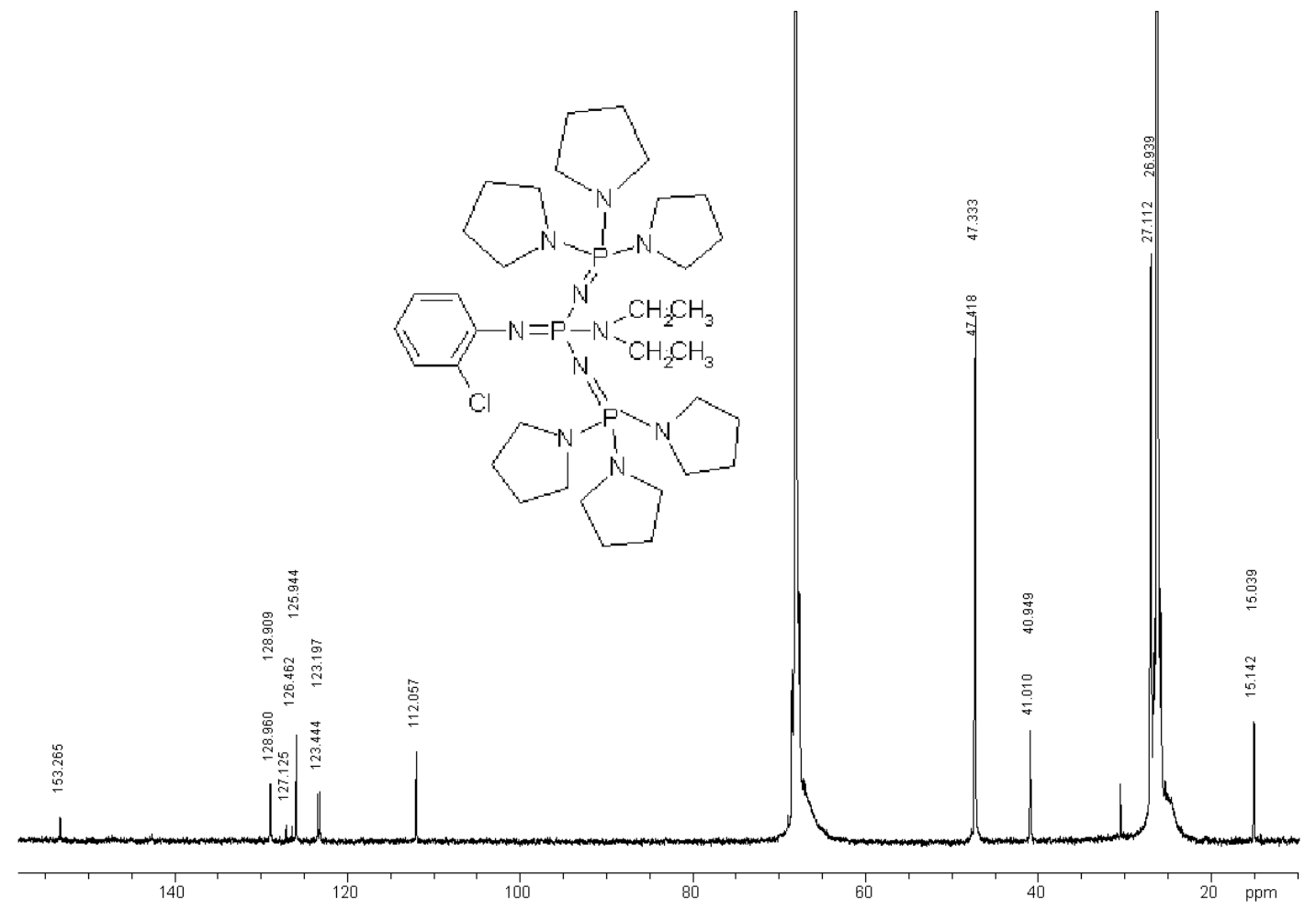

Figure S2-17. 11

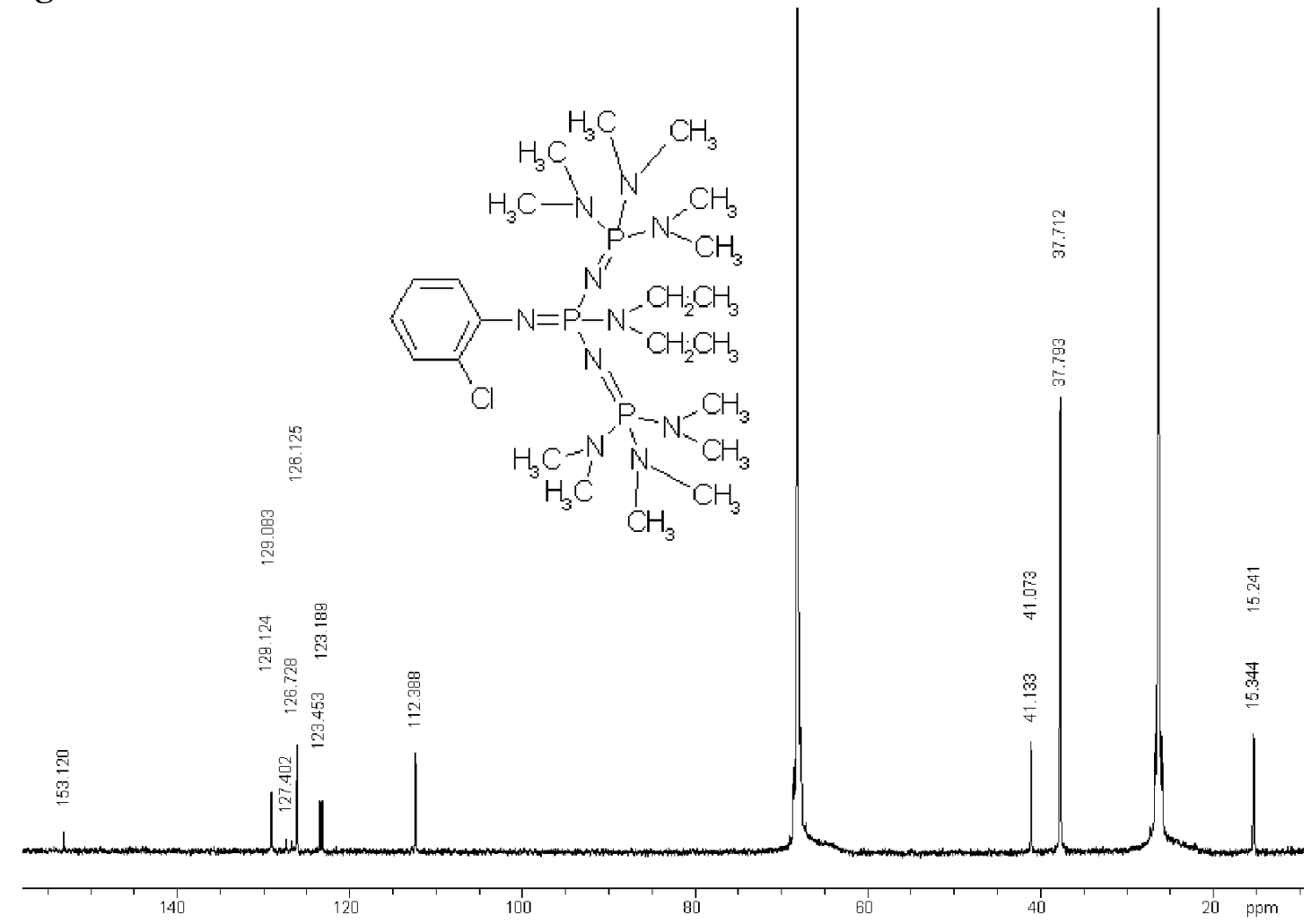

Figure S2-18. 15 


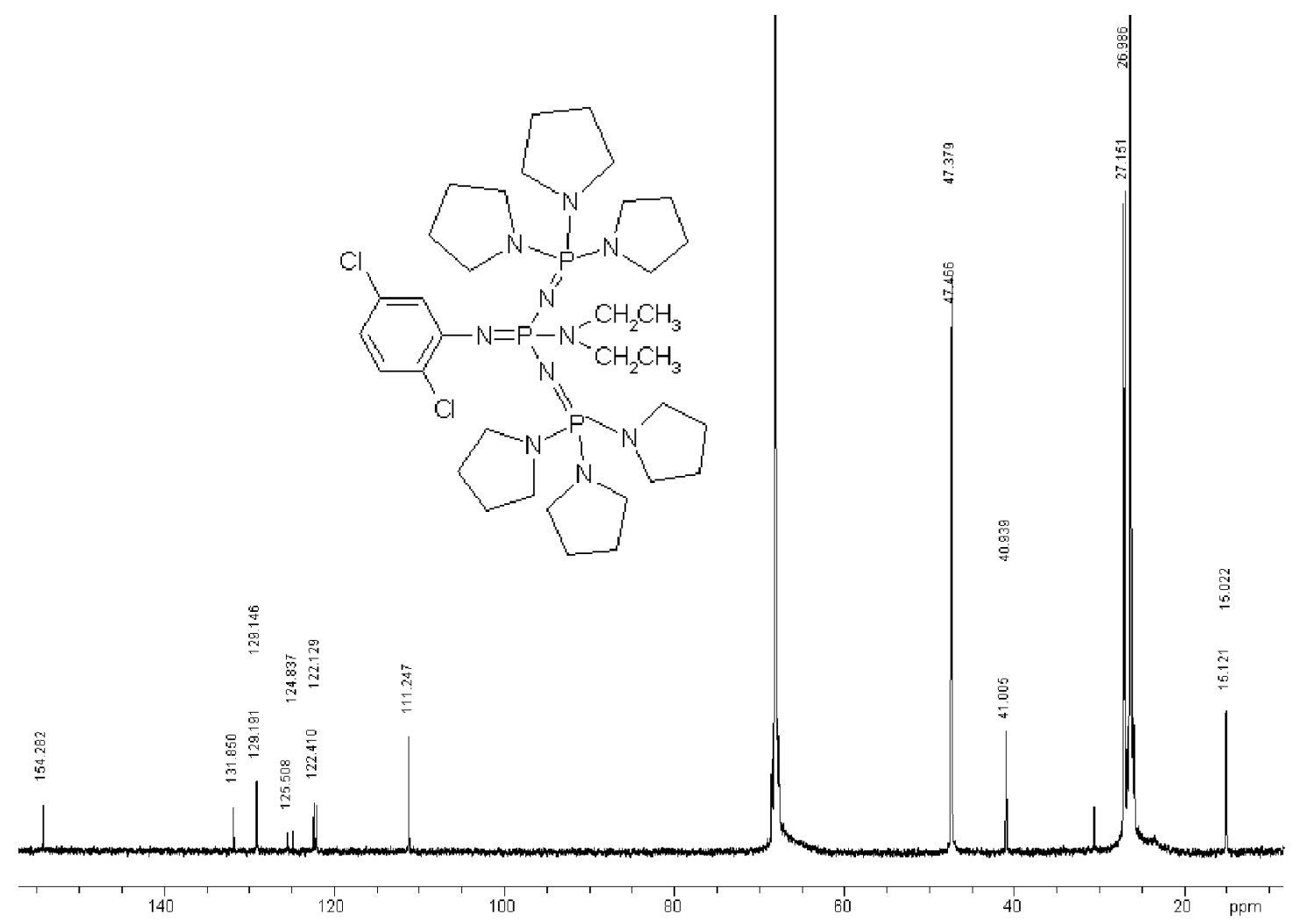

Figure S2-19. 20

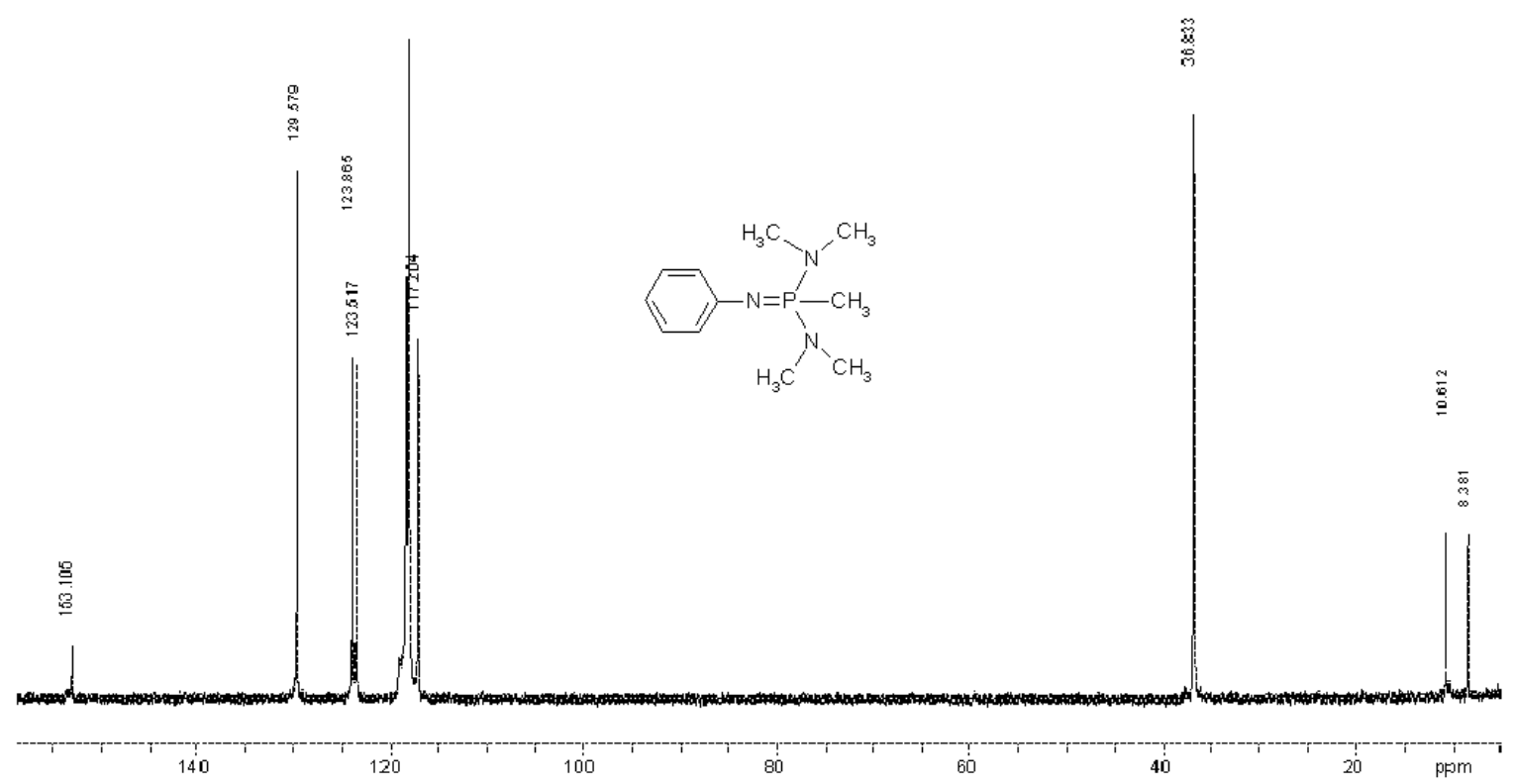

Figure S2-20. 29 